\begin{tabular}{|c|c|}
\hline $\begin{array}{l}\text { APR } 011999(21 \text { ) ENGINEERING DATA TRANSMITTAL } \\
\text { Station } 15\end{array}$ & 1. EDT $\quad 620481$ \\
\hline
\end{tabular}

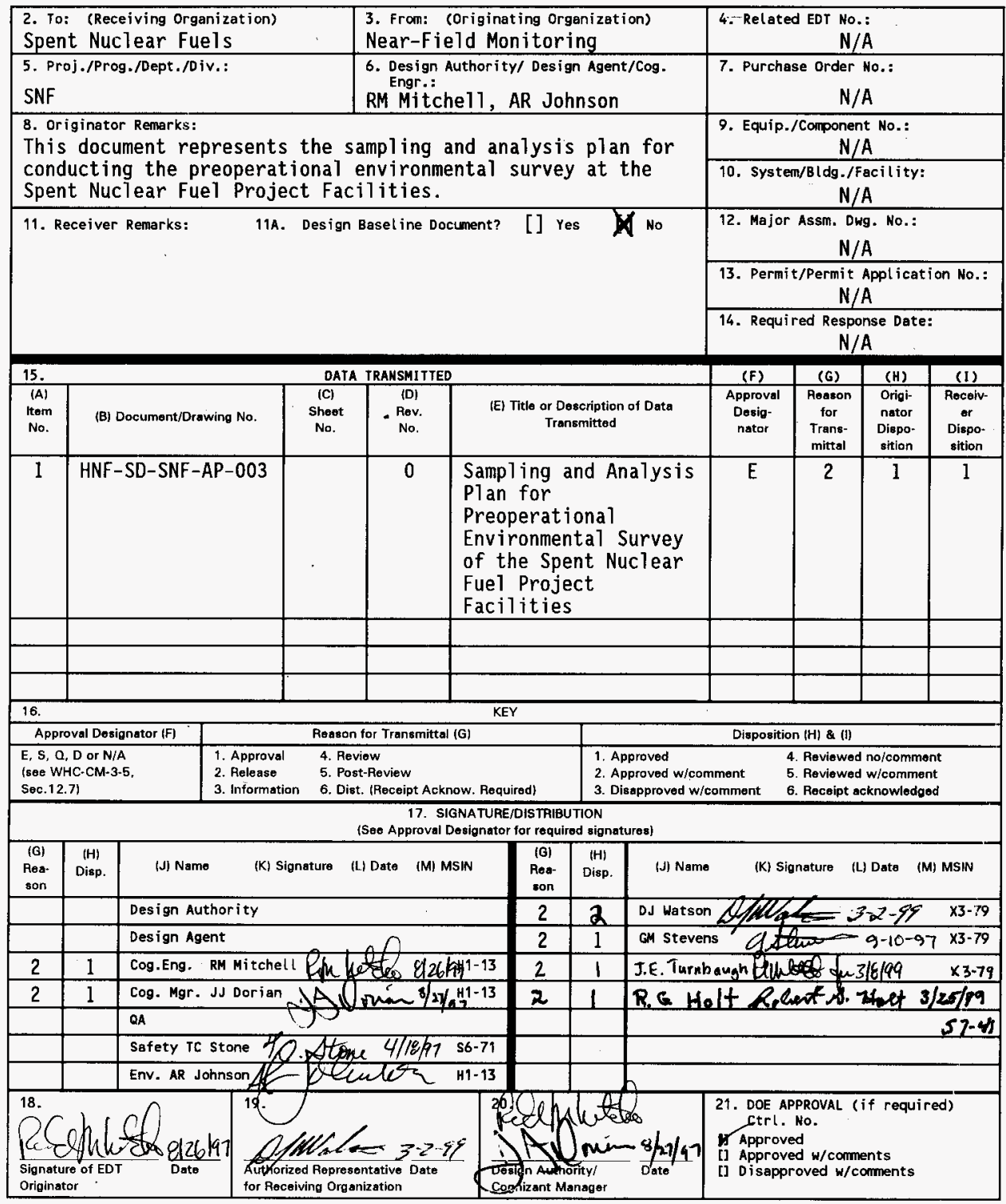

BD-7400-172-2(05/96) GEF097 


\title{
Sampling and Analysis Plan for the Preoperational Environmental Survey of the Spent Nuclear Fuel Project Facilities
}

\author{
R. M. Mitche11, B. M. Markes, C. J. Perkins \\ Waste Management Federal Services, Inc., \\ Northwest Operations, Richland, WA 99352 \\ for Fluor Daniel Hanford, Inc. \\ U.S. Department of Energy Contract DE-AC06-96RL13200

$\begin{array}{lll}\text { EDT/ECN: } & \text { EDT } 620481 & \text { UC: } 2070 \\ \text { Org Code: } & \text { 2K200 } & \text { Task order: GS080003 } \\ \text { CACN/COA: } & 105650 / C A 40(50 \%) & \text { Project/Crosswalk: 772032/107 } \\ \text { CACN/C0A: } & 106789 / C A 40(50 \%) & \\ \text { B\&R Code: } & \text { EW7040000 } & \text { Total Pages: } 38\end{array}$

Key Words: site characterization, preoperational survey, environmental baseline, radiological, Canister Storage Building

Abstract: This document represents the sampling analysis plan for conducting environmental sampling of soil, vegetation, litter, cryptogams, and small mammals at the Spent Nuclear Fuel Project

facilities in support of the preoperational environmental survey.

TRADEMARK DISCLAIMER. Reference herein to any specific commercial product, process, or service by trade name, trademark, manufacturer, or otherwise, does not necessarily constitute or imply its endorsement, recommendation, or favoring by the United States Government or any agency thereof or $i$ ts contractors or subcontractors.

Printed in the United States of America. To obtain copies of this document, contact: Document Contral Services, P.O. Box 950, Mailstop H6-08, Richland WA 99352, Phone (509) 372-2420; Fax (509) $376-4989$.
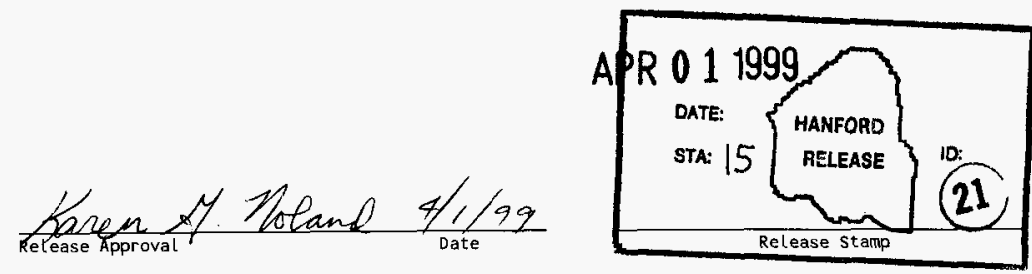


\section{SAMPLING AND ANALYSIS PLAN FOR THE PREOPERATIONAL ENVIRONMENTAL SURVEY OF THE SPENT NUCLEAR FUEL PROJECT FACILITIES}

R. M. Mitchell

B. M. Markes

C. J. Perkins

March 1999 
HNF-SD-SNF-AP-003, Rev. 0

\section{ACRONYMS}

CERCLA Comprehensive Environmental Response, Compensation and Liability Act of 1980

CFR

CSB Code of Federal Regulations

CVDF Cold Vacuum Drying Facility

DOE U.S. Department of Energy

EPA Environmental Protection Agency

ISA 200 East Interim Storage Area

$\mathrm{KE}$

$\mathrm{KW}$

K East Area/Basin

K West Area/Basin

MCOs

Multicanister overpacks

NEPA

OVM

National Environmental Policy Act of 1969

$\mathrm{QA} / \mathrm{QC}$

Organic vapor monitor

RCRA

Quality assurance/quality control

RHO

$\mathrm{SCF}$

SNF

SP

Resource Conservation and Recovery Act of 1976

TLD Rockwell Hanford Operations

WDOH

Sludge conditioning facility

Spent nuclear fuel

WHC

Standard practice

thermoluminescent dosimeter

Washington State Department of Health

Westinghouse Hanford Company 


\section{CONTENTS}

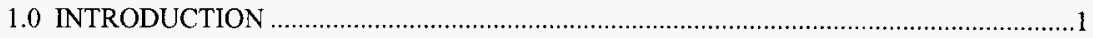

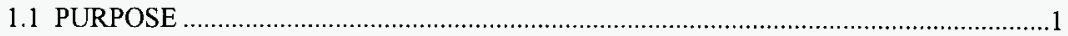

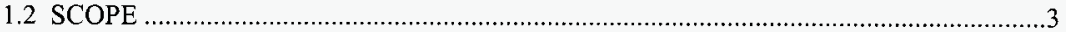

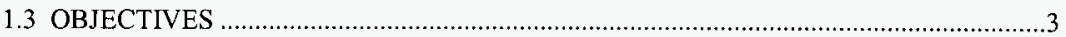

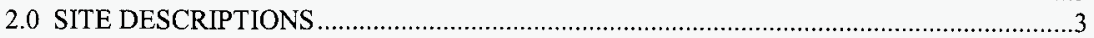

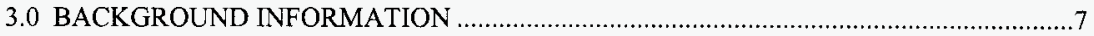

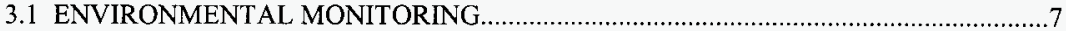

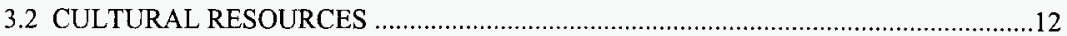

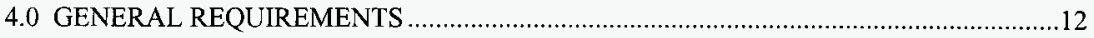

4.1 HANFORD GENERAL REQUIREMENTS .........................................................12

4.2 SPENT NUCLEAR FUELS PROJECT FACILITIES GENERAL REQUIREMENTS ....12

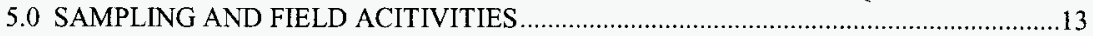

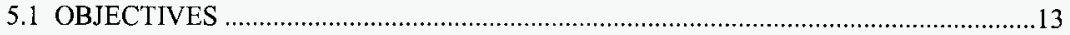

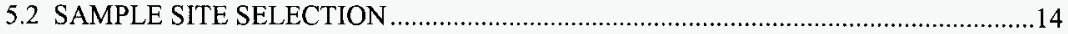

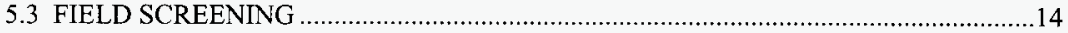

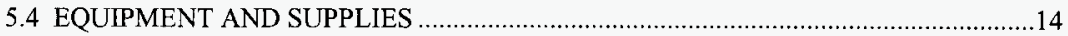

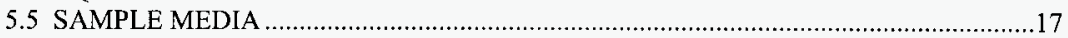

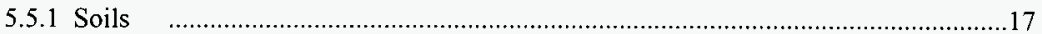

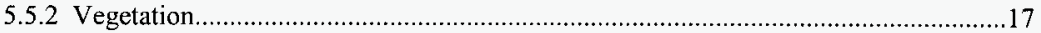

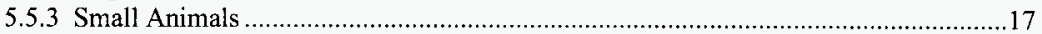

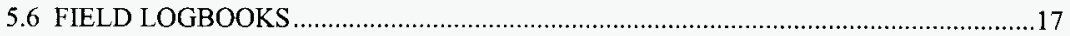

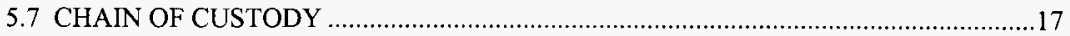

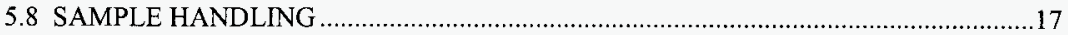

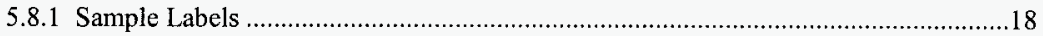

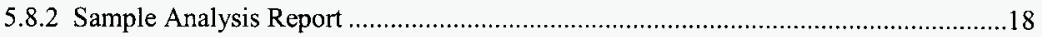

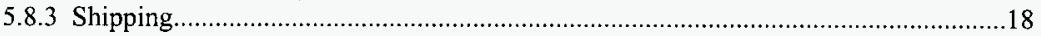

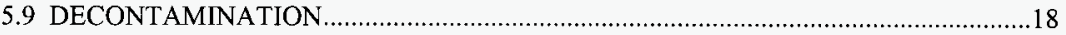

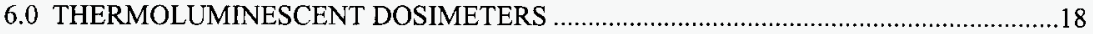

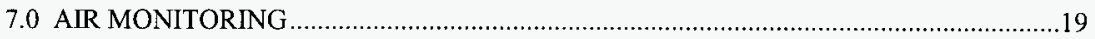

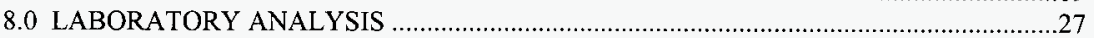

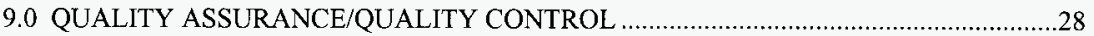

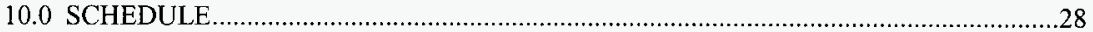

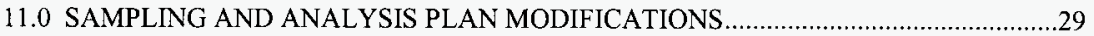

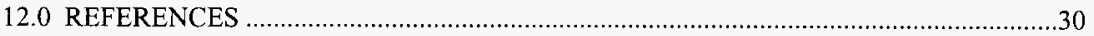




\section{TABLES}

Table 1. Average Radionuclide Concentrations (pCi/g) Detected in $100 \mathrm{~K}$ Area Surface Soil Samples from 1981 to 1993.

Table 2. Average Radionuclide Concentrations (pCi/g) Detected in $100 \mathrm{~K}$ Area Vegetation

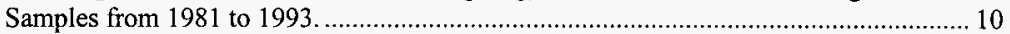

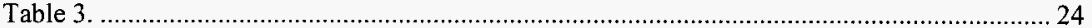

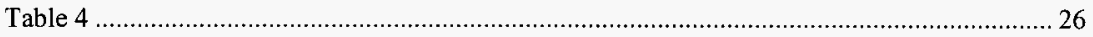

Table 5. Sample Analyses Summary.

FIGURES

Figure 1. Hanford Site showing the 100-K Area and 200 East Area.......................................... 2

Figure 2. Location of the Cold Vacuum Drying Facility in the 100-K Area of the Hanford Site. 4

Figure 3. Location of the Canister Storage Building Site............................................................ 5

Figure 4. Soil and Vegetation Sampling Locations at 100-K Area.......................................... 8

Figure 5. 200 East Soil Sampling Locations for Near-Facility Monitoring ............................... 11

Figure 6. Map of 100-K Area Showing Potential Sampling Locations..................................... 15

Figure 7. Map of 200 East Area Showing Potential Sampling Locations Around the CSB........ 16

Figure 8. Map of 100-K Area Showing TLD Monitoring Locations. ...................................... 20

Figure 9. TLD Monitoring Locations in 200 East Area............................................................. 21

Figure 10. 100-K Area Showing the Location of Air Monitoring Stations .............................. 23

Figure 11. The 200 East Area Air Monitoring Locations........................................................ 25 


\subsection{INTRODUC'TION}

This sampling and analysis plan will support the preoperational environmental monitoring for construction, development, and operation of the Spent Nuclear Fuel (SNF) Project facilities, which have been designed for the conditioning and storage of spent nuclear fuels; particularly the fuel elements associated with the operation of N-Reactor. The SNF consists principally of irradiated metallic uranium, and therefore includes plutonium and mixed fission products. The primary effort will consist of removing the SNF from the storage basins in $\mathrm{K}$ East and $\mathrm{K}$ West Areas (Figure 1), placing in multicanister overpacks, vacuum drying, conditioning, and subsequent dry vault storage in the 200 East Area.

The primary purpose and need for this action is to reduce the risks to public health and safety and to the environment. Specifically these include prevention of the release of radioactive materials into the air or to the soil surrounding the $\mathrm{K}$ Basins, prevention of the potential migration of radionuclides through the soil column to the nearby Columbia River, reduction of occupational radiation exposure, and elimination of the risks to the public and to workers from the deterioration of SNF in the K Basins (U.S. Department of Energy [DOE] 1995, 1996).

DOE Order 5400.1, General Environmental Protection Program, requires an environmental study before the startup of new facilities and processes. This DOE order is expected to become part of 10 CFR 834, Radiological Protection of the Public and the Environment, in the near future.

\subsection{PURPOSE}

The sampling and monitoring efforts described herein will be conducted primarily in support of an environmental baseline to establish the preoperational conditions at the SNF Project facilities sites in accordance with the requirements set forth in DOE Order 5400.1, Chapter IV (DOE 1990). The data obtained from the baseline sampling activities will be used to verify the following objectives:

- Identify baseline levels of contaminants in surface soits, vegetation, and the small-mammal community.

- Allow for future determination of potential impacts to the environment from SNF Project facilities construction and operation activities.

- Provide guidance for development of monitoring and surveillance requirements within, and surrounding, the SNF Project facilities. 
Figure 1. Hanford Site Showing the 100-K Area and 200 East Area.

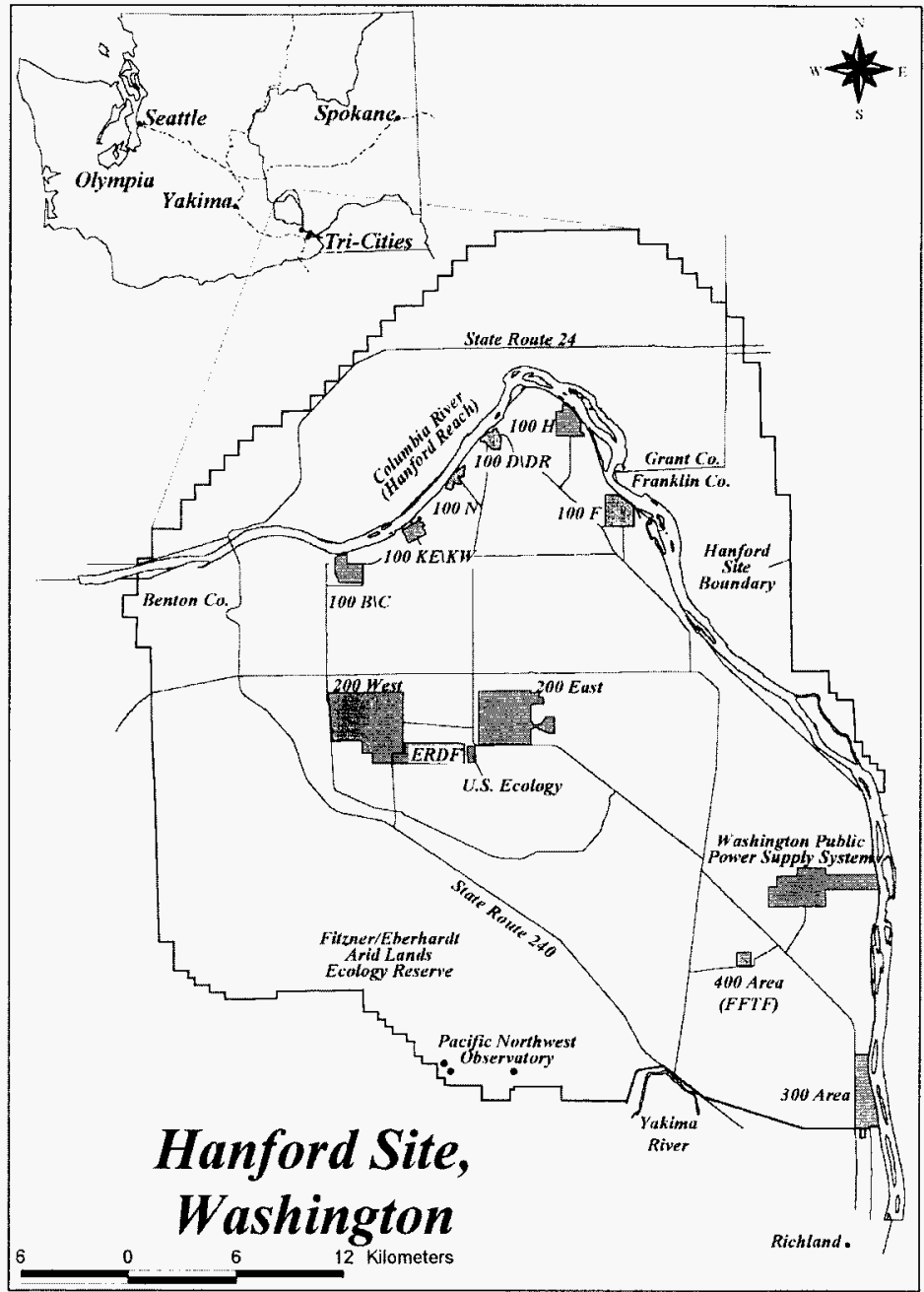




\subsection{SCOPE}

With the selection of the preferred alternative (DOE 1996, 1998) to remove the SNF from the storage basins in K East and K West, vacuum dry, condition, and provide dry vault storage, new facilities will be required. The proposed effort requires the construction of a new "ColdVacuum" Drying Facility (CVDF) location in the western portion of the $\mathrm{K}$ West Area (Figure 2). A second facility, the Canister Storage Building (CSB), along with the possible establishment of an Interim Storage Area (ISA), which is being constructed in the west-central portion of the 200 East Area (Figure 3) and will be utilized for dry vault storage. The debris and water which will be removed from the $\mathrm{K}$ East/K West storage basins will be disposed of in existing Hanford facilities. The sludge which will be removed from $100-\mathrm{K}$ East and $100-\mathrm{K}$ West Storage Basins will be conditioned at $100-\mathrm{K}$ and disposed of elsewhere at Hanford.

The focus of this survey is to determine the environmental conditions in and around the proposed CVDF in 100-K West and the CSB in 200 East.

\subsection{OBJECTIVES}

The primary objective of this preoperational survey is to establish an environmental baseline for the SNF Project facilities. This will be done to determine the environmental conditions and establish background levels for contamination that may exist within the proposed site boundaries. This effort will provide documentation of the current levels of radioactive and selected chemical contaminants in the soils, vegetation, and small-mammal community at the site. Elevated levels found during this preoperational survey, therefore, would be attributable to past practices and ongoing operations in the vicinity proximal to the location of the SNF Project facilities. The information obtained will provide guidance for the determination of potential contaminant transport pathways. This information also will assist in the development of the operational monitoring and surveillance system for early detection of potential impacts from other facility operations, or from SNF Project facilities operations to the surrounding environment.

\subsection{SITE DESCRIPTIONS}

The $100 \mathrm{~K}$ Area is located along the Columbia River approximately $3 \mathrm{~km}$ upstream of the $100 \mathrm{~N}$ Area (Figure 2). It consisted of two reactors, $\mathrm{K}$ East and $\mathrm{K}$ West whose cooling basins currently contain the Spent Nuclear Fuel (Figure 2). The 200 East Area lies on a plateau in the central portion of the Hanford Site (Figure 1) approximately $11 \mathrm{~km}$ south of the Columbia River. These two sites are the location of various radionuclide and hazardous water process facilities and waste disposal facilities (e.g., liquid waste cribs and solid waste burial grounds). 
HNF-SD-SNF-AP-003, Rev. 0

Figure 2. Location of the Cold Vacuum Drying Facility in the 100-K Area of the Hanford Site.

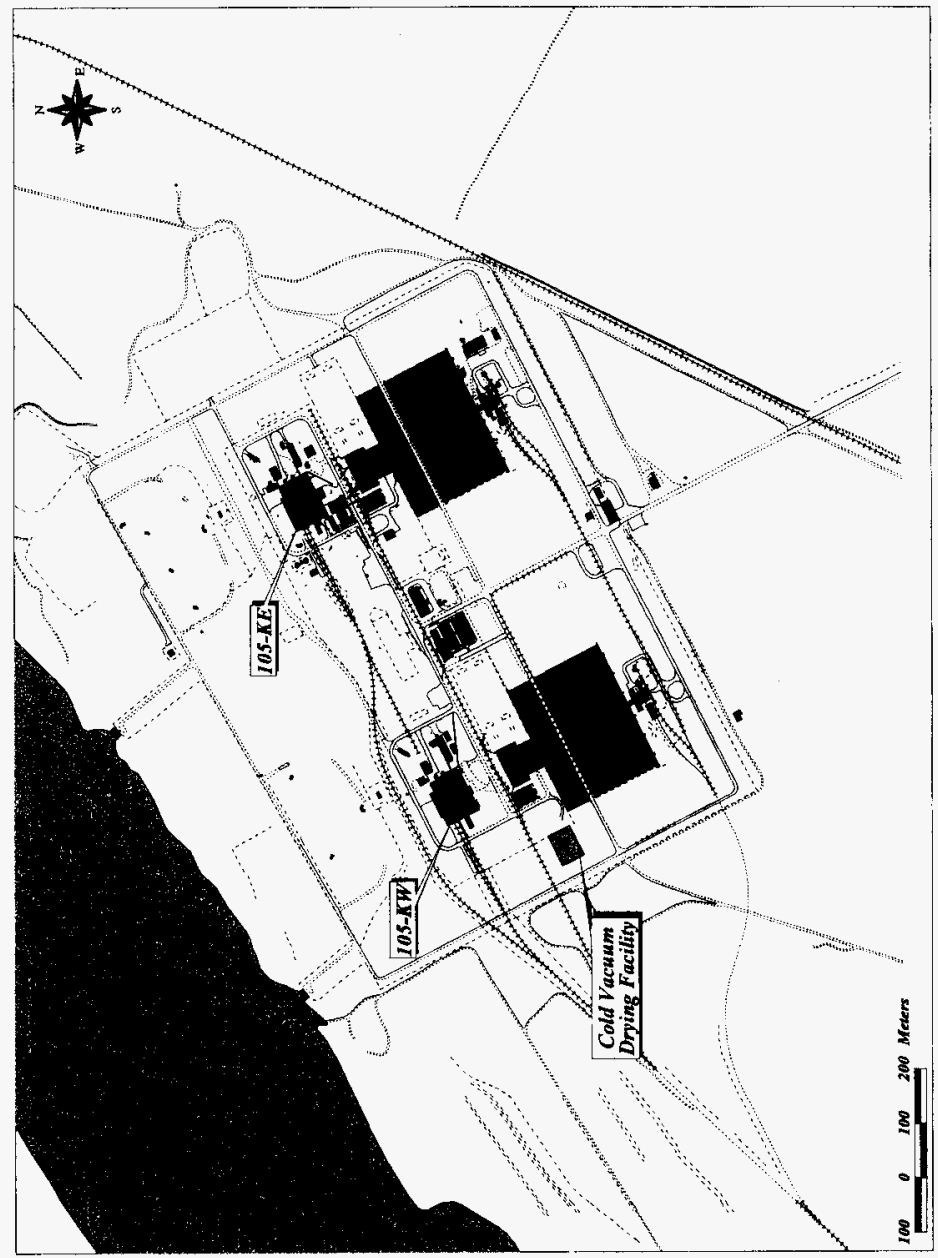


HNF-SD-SNF-AP-003, Rev. 0

Figure 3. Location of the Canister Storage Building Site.

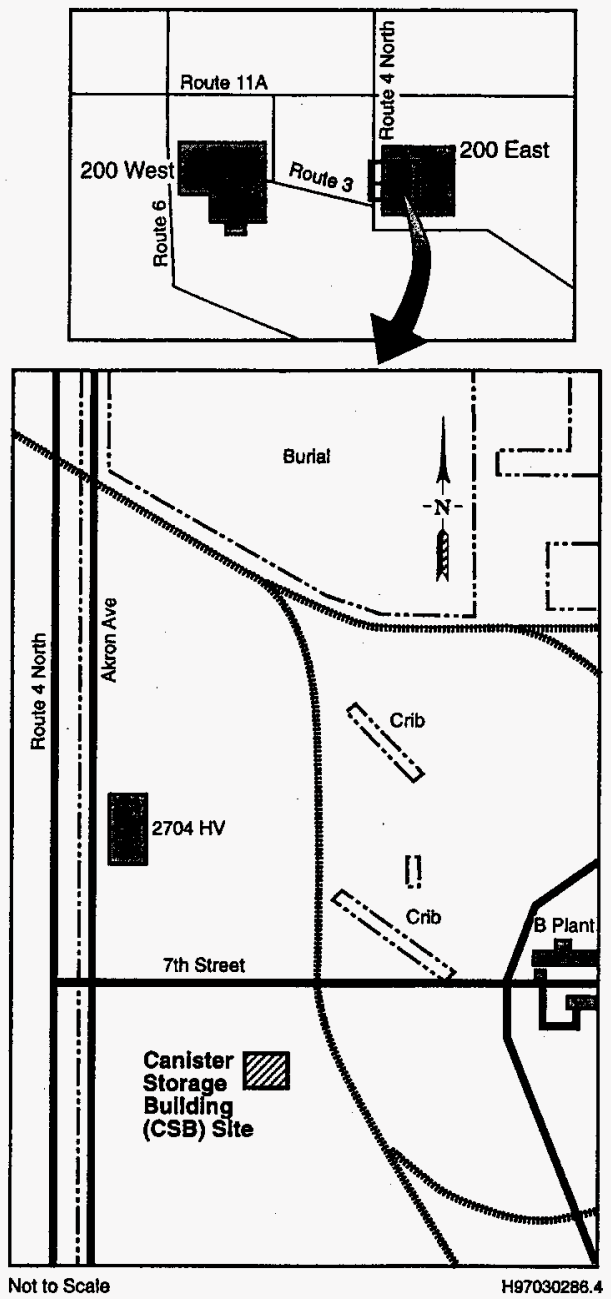


The ecology of the 200 Areas was originally mature shrub-steppe desert characterized by such vegetation as big sagebrush (Artemisia tridentata) and Sandberg's bluegrass (Poa sandbergii). Large tracts of these habitat types exist outside these areas. However, the sagebrush habitat within the areas has generally been disturbed. These disturbed areas support a variety of plants such as introduced bunchgrasses (Agropyron spp.), invaders such as Russian thistle (Salsola kali), cheatgrass (Bromus tectorum), and rabbitbrush (Chrysothamnus spp.).

Animal species of the Hanford Site, while still similar to those found before human use of the area (except certain invaders which have taken advantage of the changed habitats), are generally at reduced numbers where there is a reduction in vegetative cover and species. Native species include the long-billed curlew (Numenius americanus), the horned lark (Eremiphila alpestris), the burrowing owl (Athene cunicularia), the sage sparrow (Amphispiza belli), the loggerhead shrike (Lanius ludovicianus), the Great Basin pocket mouse (Perognathus parvus), the deer mouse (Peromyscus maniculatus), the Western harvest mouse (Reithrodontomys megalotis), the pocket gopher (Thomomys talpoides) the black-tailed jackrabbit (Lepus californicus), the badger (Taxidea taxis), and the coyote (Canis latrans).

Non-native species taking advantage of the altered habitats include the domestic pigeon (Columba livia) and the house mouse (Mus musculus). Additional information on existing habitat and associated species can be found in Neitzel (1997).

Twelve plant species considered to be endangered, threatened, or sensitive by the Washington Natural Heritage Program (1994) are known to survive on or near the Hanford Site, seven of which are upland species (Sackschewsky et al. 1992). The upland species are northern wormwood (Artemisia campestris spp. Borealis var. wormskiodii) Hoover's desert parsley (Lomatium tuberosum), Piper's daisy (Erigeron piperianus), gray cryptantha (Cryptantha leucophea), Palouse milkvetch (Astragalus arrectus), and coyote tobacco (Nicotiana attenuata). Currently, none of the plant species are listed as federal threatened or endangered species. However, three local upland species are candidates for federal protection: (1) northern wormwood, (2) Hoover's desert parsley, and (3) Columbia milkvetch.

The bald eagle and peregrine falcon are the only federally listed threatened or endangered wildlife species occurring near the 200 Areas. Federal candidate species occurring near the 200 Areas include the ferrunginous hawk and loggerhead shrike. The pygmy rabbit, a shrubsteppe species listed as a federal candidate species and state threatened species, has not been observed on the Hanford Site since 1984 (Fitzner et al. 1992). The sage grouse, another federal candidate shrub-steppe species, has not been observed at the Hanford Site since the mid-1980's and probably no longer resides at the Site (Landeen et al. 1992). State listed threatened or endangered wildlife includes the peregrine falcon and ferruginous hawk. State candidate species observed near the 200 Areas include the golden eagle, burrowing owl, sage thrasher, Swainson's hawk, striped whipsnake, Merriam's shrew, and sage sparrow (Stegen 1992).

The specific areas comprising the proposed facilities are generally devoid of native vegetation, which over the years has been disturbed by various waste management activities, as well as construction of roads, buildings, storage basins, and other facilities. Therefore, the human activities and ongoing construction efforts have greatly reduced the likelihood that any 
HNF-SD-SNF-AP-003, Rev. 0

protected species occur in the near vicinity. During the sampling activities, biologists will survey the work areas for any species of concern.

\subsection{BACKGROUND INFORMATION}

Environmental monitoring efforts to determine radionuclide levels in the $100 \mathrm{~K}$ and 200 East Areas have been conducted by Rockwell Hanford Operations (RHO) and Westinghouse Hanford Company (WHC) in association with the burial grounds, liquid waste disposal facilities, and waste management activities conducted within and around these sites (Panesko et al. 1977; Panesko et al. 1978; Houston and Blumer 1978, 1979a, 1979b; Schmidt et al. 1990, 1991, 1992a, 1992b, 1993, 1994, 1995, 1996; Perkins 1988, 1990, 1991, 1992; Perkins et al. 1997, 1998).

\subsection{ENVIRONMENTAL MONITORING}

$\underline{100 \mathrm{~K}}$

Soil and vegetation sampling has been conducted on a routine basis since 1981 at five locations near burial grounds and liquid effluent disposal facilities associated with past reactor operations located in the northeast perimeter of the $100 \mathrm{~K}$ Area (Figure 4). Routine sampling at these sites was discontinued in 1993 (Schmidt et al. 1995). Table 1 provides a summary of the average radionuclide values detected in $100 \mathrm{~K}$ surface soil samples near the burial grounds from 1981 through 1993 (Schmidt et al. 1994). Table 2 is a summary of the average radionuclide values found in vegetation samples collected from the $100 \mathrm{~K}$ Area from 1981 to 1993 (Schmidt et al. 1994). With the exception of ${ }^{90} \mathrm{Sr}$ in soils and plants, there has been a trend toward decreasing values for the other radionuclide values listed. Although these samples are from a location somewhat distant from the proposed cold-vacuum drying facility location (Figure 2), they provide a useful baseline for comparative purposes with the data developed during this study. 
HNF-SD-SNF-AP-003, Rev. 0

Figure 4. Soil and Vegetation Sampling Locations at 100-K Area.

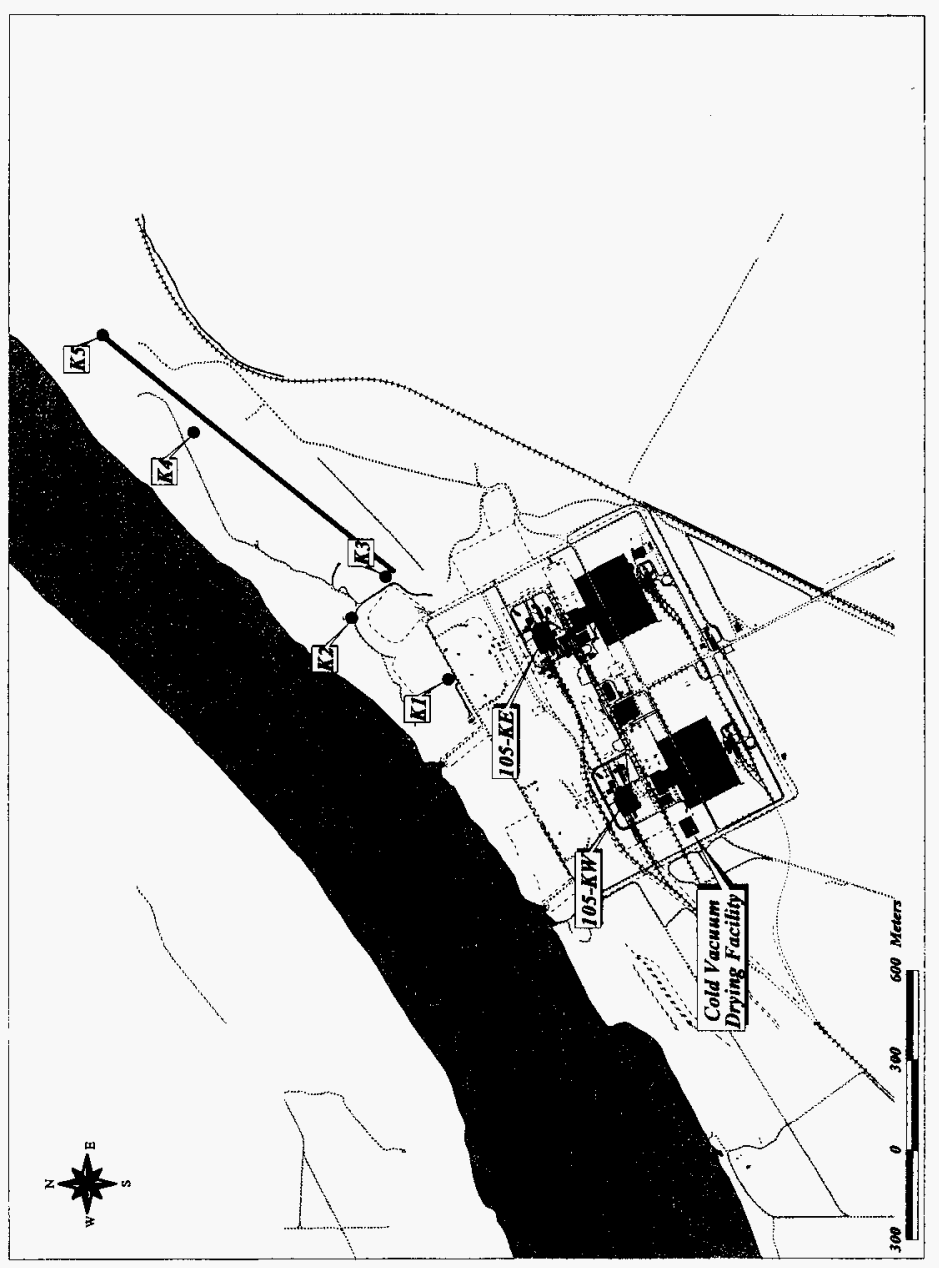


HNF-SD-SNF-AP-003, Rev. 0

Table 1. Average Radionuclide Concentrations (pCi/g) Detected in $100 \mathrm{~K}$ Area Surface Soil Samples from 1981 to 1993.

\begin{tabular}{|c|c|c|c|c|c|}
\hline Year & ${ }^{60} \mathrm{Co}$ & ${ }^{90} \mathrm{Sr}$ & ${ }^{137} \mathrm{Cs}$ & ${ }^{238} \mathrm{Pu}$ & ${ }^{239,240} \mathrm{Pu}$ \\
\hline 1981 & $8.3 \mathrm{E}-01$ & $\mathrm{NR}$ & $4.4 \mathrm{E}+00$ & $\mathrm{NR}$ & $\mathrm{NR}$ \\
\hline 1982 & $2.6 \mathrm{E}+01$ & $\mathrm{NR}$ & $8.8 \mathrm{E}-01$ & $\mathrm{NR}$ & $\mathrm{NR}$ \\
\hline 1983 & $5.5 \mathrm{E}+01$ & $\mathrm{NR}$ & $5.3 \mathrm{E}+01$ & $\mathrm{NR}$ & $\mathrm{NR}$ \\
\hline 1984 & $3.3 \mathrm{E}+00$ & $8.4 \mathrm{E}-01$ & $1.2 \mathrm{E}+01$ & $9.6 \mathrm{E}-04$ & $2.9 \mathrm{E}-02$ \\
\hline 1985 & $7.4 \mathrm{E}-01$ & $2.9 \mathrm{E}-01$ & $1.1 \mathrm{E}+00$ & $1.4 \mathrm{E}-03$ & $3.2 \mathrm{E}-02$ \\
\hline 1986 & $1.0 \mathrm{E}+00$ & $1.8 \mathrm{E}-01$ & $1.1 \mathrm{E}+00$ & $9.1 \mathrm{E}-04$ & $2.3 \mathrm{E}-02$ \\
\hline 1987 & $1.2 \mathrm{E}+00$ & $4.3 \mathrm{E}-01$ & $1.3 \mathrm{E}+00$ & $2.7 \mathrm{E}-03$ & $5.5 \mathrm{E}-02$ \\
\hline 1988 & $3.9 \mathrm{E}-01$ & $2.3 \mathrm{E}-01$ & $7.3 \mathrm{E}-01$ & $7.1 \mathrm{E}-04$ & $2.0 \mathrm{E}-02$ \\
\hline 1989 & $7.7 \mathrm{E}-01$ & $6.3 \mathrm{E}-01$ & $7.5 \mathrm{E}+00$ & $2.8 \mathrm{E}-03$ & $7.8 \mathrm{E}-02$ \\
\hline 1990 & $2.3 \mathrm{E}-01$ & $2.3 \mathrm{E}-01$ & $9.7 \mathrm{E}-01$ & $6.8 \mathrm{E}-04$ & $1.4 \mathrm{E}-02$ \\
\hline 1991 & $2.7 \mathrm{E}-01$ & $1.7 \mathrm{E}-01$ & $1.2 \mathrm{E}+00$ & $8.6 \mathrm{E}-04$ & $2.0 \mathrm{E}-02$ \\
\hline 1992 & $1.3 \mathrm{E}-01$ & $2.5 \mathrm{E}-01$ & $5.3 \mathrm{E}-01$ & $5.7 \mathrm{E}-04$ & $1.3 \mathrm{E}-02$ \\
\hline 1993 & $7.5 \mathrm{E}-02$ & $2.0 \mathrm{E}-01$ & $5.0 \mathrm{E}-01$ & $2.4 \mathrm{E}-04$ & $7.0 \mathrm{E}-03$ \\
\hline
\end{tabular}

$\mathrm{NR}=$ Not reported. 
Table 2. Average Radionuclide Concentrations (pCi/g) Detected in $100 \mathrm{~K}$ Area Vegetation Samples from 1981 to 1993.

\begin{tabular}{|c|c|c|c|c|c|}
\hline Year & ${ }^{60} \mathrm{Co}$ & ${ }^{90} \mathrm{Sr}$ & ${ }^{137} \mathrm{Cs}$ & ${ }^{238} \mathrm{Pu}$ & ${ }^{239,240} \mathrm{Pu}$ \\
\hline 1981 & $1.2 \mathrm{E}+00$ & $\mathrm{NR}$ & $1.0 \mathrm{E}-01$ & $\mathrm{NR}$ & $\mathrm{NR}$ \\
\hline 1982 & $2.4 \mathrm{E}-01$ & $\mathrm{NR}$ & $9.7 \mathrm{E}-01$ & $\mathrm{NR}$ & $\mathrm{NR}$ \\
\hline 1983 & $1.5 \mathrm{E}-01$ & $\mathrm{NR}$ & $2.5 \mathrm{E}-01$ & $\mathrm{NR}$ & $\mathrm{NR}$ \\
\hline 1984 & $1.8 \mathrm{E}-01$ & $1.3 \mathrm{E}+00$ & $1.3 \mathrm{E}-01$ & $2.9 \mathrm{E}-04$ & $6.9 \mathrm{E}-04$ \\
\hline 1985 & $4.6 \mathrm{E}-01$ & $3.9 \mathrm{E}-01$ & $1.3 \mathrm{E}-01$ & $1.9 \mathrm{E}-04$ & $7.1 \mathrm{E}-04$ \\
\hline 1986 & $2.8 \mathrm{E}-01$ & $4.0 \mathrm{E}-01$ & $1.5 \mathrm{E}+00$ & $2.5 \mathrm{E}-04$ & $7.9 \mathrm{E}-04$ \\
\hline 1987 & $2.3 \mathrm{E}-01$ & $1.3 \mathrm{E}+00$ & $1.1 \mathrm{E}-01$ & $1.9 \mathrm{E}-04$ & $2.2 \mathrm{E}-04$ \\
\hline 1988 & $4.9 \mathrm{E}-01$ & $1.2 \mathrm{E}+00$ & $1.8 \mathrm{E}-01$ & $5.2 \mathrm{E}-05$ & $3.8 \mathrm{E}-04$ \\
\hline 1989 & $3.1 \mathrm{E}-01$ & $1.3 \mathrm{E}+00$ & $1.6 \mathrm{E}-01$ & $1.1 \mathrm{E}-04$ & $1.5 \mathrm{E}-04$ \\
\hline 1990 & $4.5 \mathrm{E}-02$ & $8.0 \mathrm{E}+00$ & $4.1 \mathrm{E}-02$ & $-1.7 \mathrm{E}-04$ & $2.5 \mathrm{E}-04$ \\
\hline 1991 & $6.3 \mathrm{E}-02$ & $4.1 \mathrm{E}-01$ & $7.6 \mathrm{E}-02$ & $5.2 \mathrm{E}-05$ & $5.9 \mathrm{E}-04$ \\
\hline 1992 & $-4.2 \mathrm{E}-02$ & $5.3 \mathrm{E}-01$ & $3.8 \mathrm{E}-02$ & $-6.5 \mathrm{E}-05$ & $9.8 \mathrm{E}-05$ \\
\hline 1993 & $-1.3 \mathrm{E}-02$ & $4.5 \mathrm{E}-01$ & $-3.0 \mathrm{E}-02$ & $-9.1 \mathrm{E}-05$ & $-1.4 \mathrm{E}-04$ \\
\hline
\end{tabular}

NR $=$ Not reported

Negative value indicates results at or below background levels of radioactivity.

$\underline{200 \text { East }}$

Soil and vegetation sampling has been conducted on a routine basis in the 200 Areas and surrounding environs for a number of years. A sample site (D080) located southeast of the CSB near the Cross-Site Transfer Line (Figure 5) has been sampled biannually for the last six years. Sample values collected during the preoperational survey for the Cross-Site Transfer Line will also be utilized for providing a comparative baseline (Johnson and Mitchell 1996). Information from another sample site (D062), which is sampled less frequently and located near the B-55 and B-12 Cribs, will also be utilized (Figure 5). Both of these sites are located east of the CSB in association with waste facilities. Although the prevailing winds are out of the west, easterly winds blowing off these sites toward the CSB do occur annually between 18 to 22 percent of the time.

Additionally, information available in the "Hanford Waste Vitrification Project (HWVP) Baseline Summary Report" (Wasmiller 1993) will be utilized where possible to aid in the development of the environmental baseline for the CSB.

In summary, since the $100 \mathrm{~K}$ and 200 East proposed facility sites comprise largely disturbed areas located proximal to a number of waste sites and active facilities, the utilization of the previously developed historical data will allow for collection of a minimal number of additional samples in the appropriately selected media. This determination is in concert with the recommendations in DOE Order 5400.1 to utilize existing data. 
Figure 5. 200 East Soil Sampling Locations for Near-Facility Monitoring

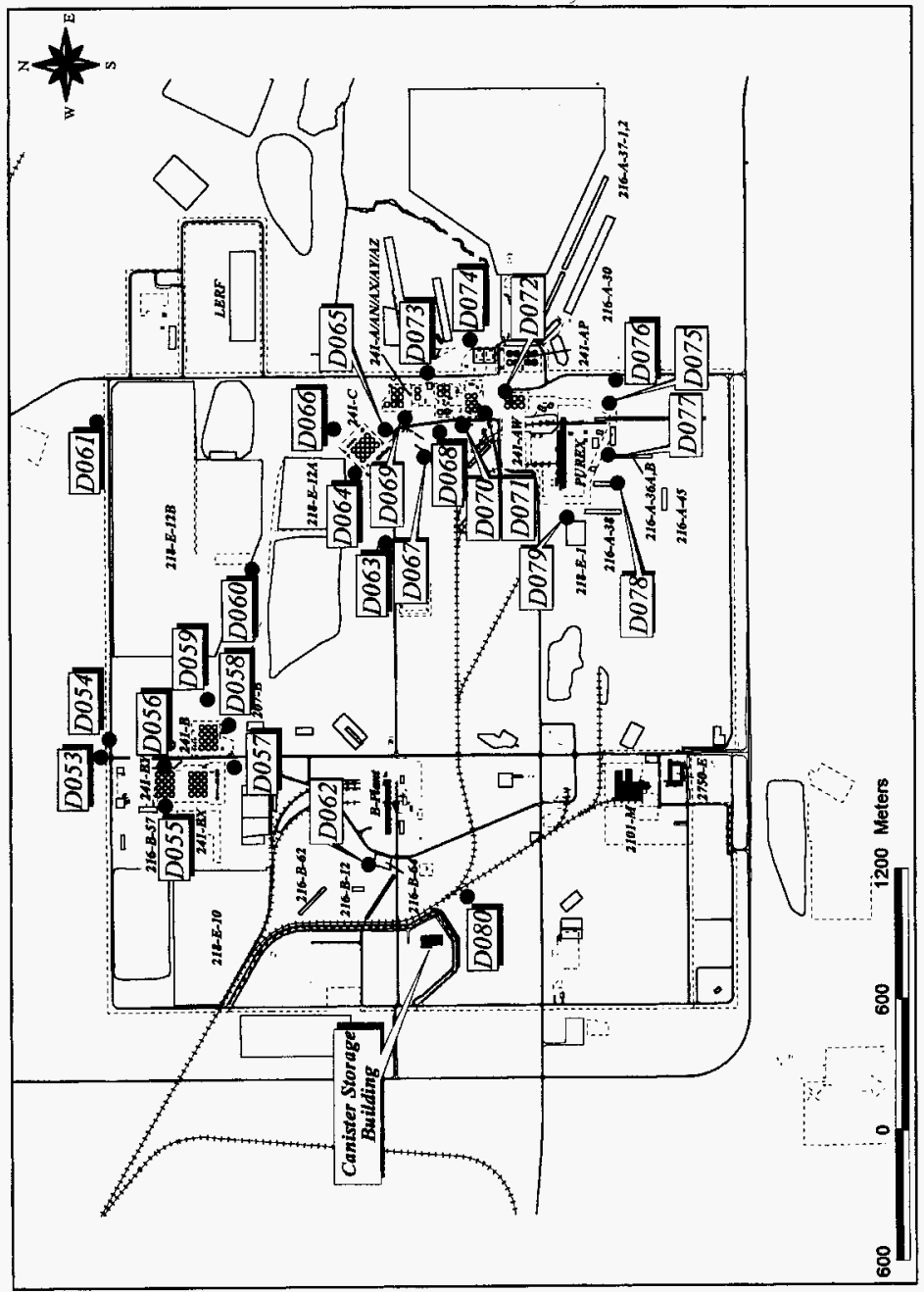




\subsection{CULTURAL RESOURCES}

The potential impacts of removing SNF from the $\mathrm{K}$ Basins, processing it, and storing it on a long-term basis have previously been reviewed (DOE 1995, 1996, 1998). The 100-K facility and 200 East facility are both located inside the fenced portions of the site, which have received extensive review (Chatters and Cadoret 1990). No known archaeological or historical sites are located within the proposed project sites. However, sampling personnel will be informed to be on the lookout for any cultural resources and to notify the responsible personnel.

\subsection{GENERAL REQUIREMENTS}

\subsection{HANFORD GENERAL REQUIREMENTS}

All personnel supporting this effort will have completed the applicable training and will perform work in accordance with the following:

- Operational Environmental Monitoring, WMNW-CM-004.

- Near-Facility Environmental Monitoring Quality Assurance Project Plan, HNF-EP-0538-3 (WMNW 1997).

- Environmental Training, HNF-PRO-459.

- Quality Assurance Program Plans, HNF-PRO-261.

- Safety and Environmental Reference Manual, WMNW-SERM-001.

- Site-specific health and safety plans, and Activity Hazard Analysis.

- Site-specific facility orientation.

\subsection{SPENT NUCLEAR FUELS PROJECT FACILITIES GENERAL REQUIREMENTS}

The requirements and procedures applicable to the SNF Project facilities field sampling activities are specified in the Sampling Services Procedures Manual, ES-SSPM-001. Applicable guidelines and procedures may include the following:

- Standard Practice (SP) 1-1, "Chain of Custody."

- SP 1-2, "Project and Sample Identification for Sampling Services."

- SP 1-3, "Control of Certificates of Analysis." 
- SP 1-5, "Field Logbooks."

- SP 2-1, "Bottle Preservation."

- SP 2-5, "Laboratory Cleaning of Sampling Equipment."

- SP 2-6, "Sample Packaging and Shipping."

- SP 4-1, "Solid Sampling."

- SP 6-1, "Calibration and Control of Monitoring Instruments."

The field activities will conform to the requirements of a site-specific safety assessment to be completed before the initiation of sampling activities. A pre-job safety meeting, including any personnel associated with the fieldwork, will be held before the performance of the sampling effort. Comments and concerns will be addressed and resolved at that time.

An Activity Hazard Analysis Checklist will be developed for use by all parties involved in sampling activities or visiting the sample locations. A tailgate safety meeting will be held at the job site each day prior to commencement of operations.

\subsection{SAMPLING AND FIELD ACTIVITIES}

Sampling efforts for the SNF Project facilities will focus on the collection of environmental data and media, which include soil, vegetation, thermoluminescent dosimeters (TLDs [external radiation]) and air, as well as small mammals. Historical information has been reviewed and evaluated to determine the types of samples needed, the analyses required for potential contaminants of concern, and prospective sample site selection.

\subsection{OBJECTIVES}

The primary objectives of the preoperational survey include the following: (1) determining current levels of radionuclides in environmental media attributable to previous and on-going operations of other waste management facilities in the area; (2) providing data that will demonstrate the level of potential environmental impacts during SNF Project facilities construction and operations and, possibly, when corrective actions may be necessary; (3) characterizing existing levels of radionuclides in the selected media and other environmental pollutants for comparison of past and future trends for the enhancement of routine operational monitoring; and (4) identifying potential pathways for human exposure and environmental impacts. 


\subsection{SAMPLE SITE SELECTION}

Before the initiation of sampling activities, a detailed map of the SNF Project facilities has been obtained that shows the location of existing and proposed buildings, facilities, and other structures. The location of nearby waste sites, such as burial grounds, cribs, ditches, and ponds, has been noted in the field logbook. Using the map, both sites will be reconnoitered to determine the prime areas for the location of sampling points (Figures 6 and 7). Each sample site will be marked with a surveyor's stake and noted on a map, which will be included in the field logbook.

All of the staked locations will be surveyed with a Trimble 4000 SSi 9 channel Global Positioning System receiver and reduced to Washington State Plane (south zone) North American Datum of 1983; 1991 adjustment in meters.

\subsection{FIELD SCREENING}

Field screening will be utilized to assist in the selection of samples to be submitted for laboratory analyses. Soils from potential sampling locations will be observed for discoloration, excessive moisture, or other anomalies. Any soils demonstrating these characteristics will be screened utilizing an organic vapor monitor and results recorded in the field logbook. Soils exhibiting positive readings for volatile organic constituents may be submitted for analyses. Collected samples will also be screened for radioactivity utilizing a Geiger-Muller counter and an alpha detector.

\subsection{EQUIPMENT AND SUPPLIES}

The following materials and equipment may be required to perform the outlined tasks:

- Plastic sampling jars.

- Glass sampling jars.

- Sample jars labels.

- Protective gloves.

- Ice chest with wet or "blue" ice.

- Absorbent (vermiculite) for shipping.

- Permanent marking pens.

- Safety glasses.

- Sampling devices (trowels, spoons, augers, shovels).

- Plastic sealer bags.

- Evidence tape.

- Measuring tape.

- Other items as needed. 
HNF-SD-SNF-AP-003, Rev. 0

Figure 6. Map of 100-K Area Showing Potential Sampling Locations.

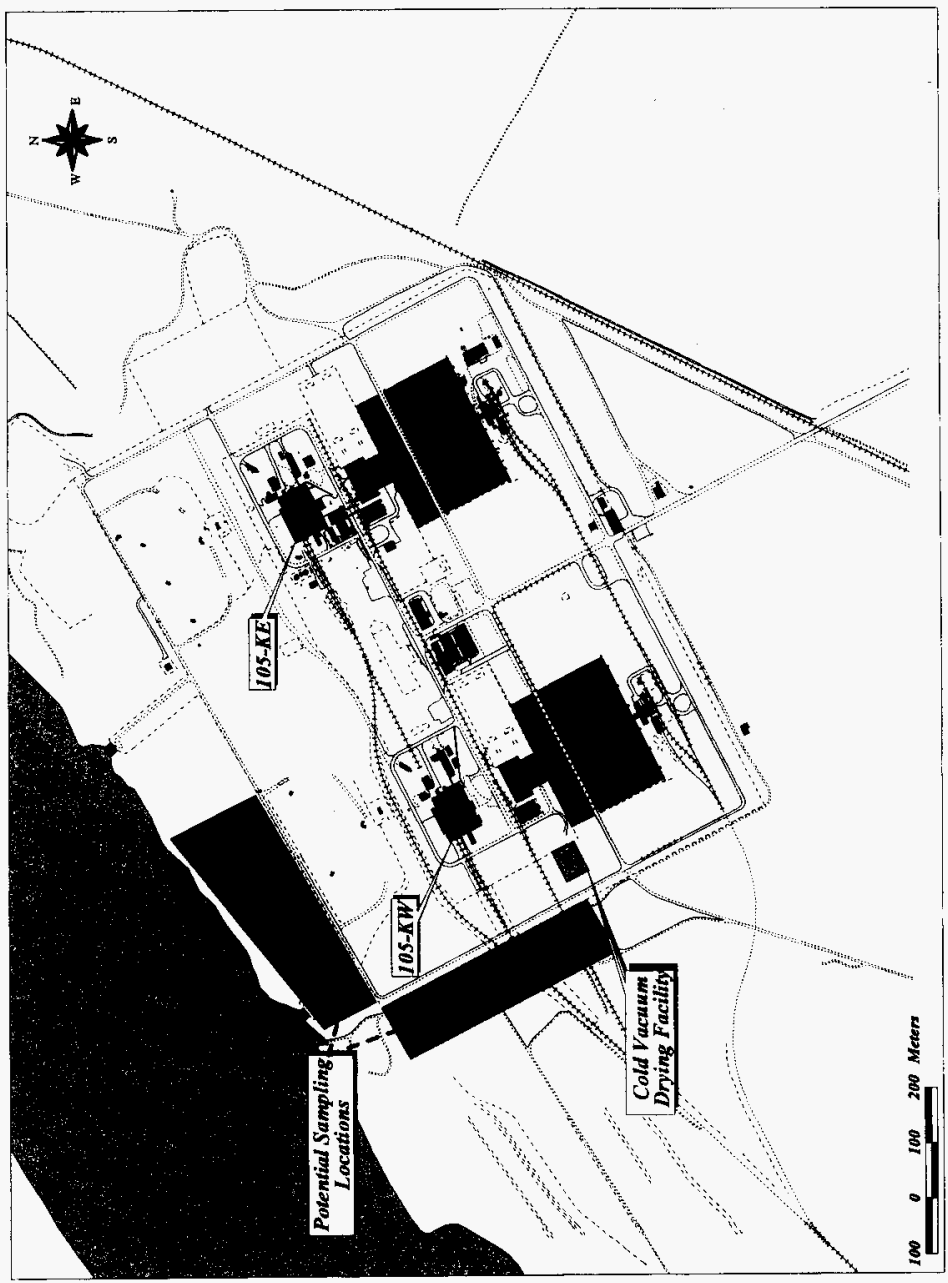


Figure 7. Map of 200 East Area Showing Potential Sampling Locations Around the CSB.

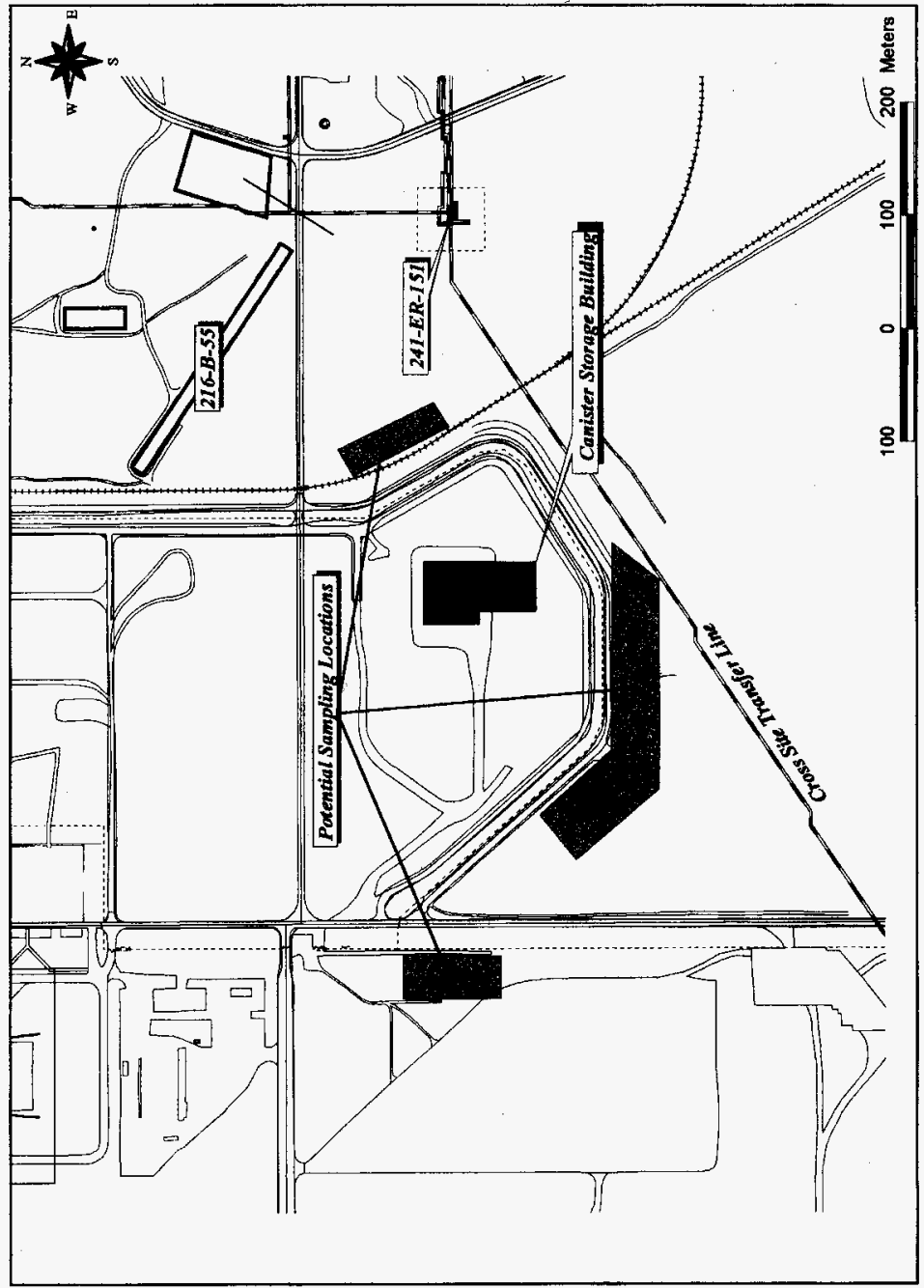




\subsection{SAMPLE MEDIA}

\subsubsection{Soils}

Soil samples will be collected and preserved in accordance with the requirements outlined in SP 4-1, "Solid Sampling: Soil and Sediment Sampling." For the purposes of this sampling, undisturbed surface soils will be collected to a depth of $2.5 \mathrm{~cm}$.

\subsubsection{Vegetation}

Deep-rooted shrubs, and possibly grasses, will be collected in accordance with "Vegetation Sampling" (WMNW-CM-004).

\subsubsection{Small Animals}

The collection and preservation of small mammal samples will be conducted following the guidance provided in "Animal Sampling" (WMNW-CM-004).

\subsection{FIELD LOGBOOKS}

Field activities will be recorded in a field logbook according to the protocol outline in SP 1-5, "Field Logbooks." Entries will be made in ink, signed, and dated, Photographs will be taken during sampling and to document any unusual circumstances encountered during the investigation.

\subsection{CHAIN OF CUSTODY}

Chain of custody records will be maintained in accordance with the requirements of SP 1-1, "Chain of Custody/Sample Analysis Request." The chain of custody form will establish the documentation necessary to ensure the traceability of the sample from time of collection until disposal.

\subsection{SAMPLE HANDLING}

Following collection, samples will be controlled in accordance with the requirements outlined in SP 2-6, "Sample Packaging and Shipping." All samples will be labeled, sealed, and placed in a container for preservation on ice or other appropriate cooling medium. 


\subsubsection{Sample Labels}

Each sample will be identified and labeled with a unique sample number. Numbers will be assigned in the field per SP 1-2, "Project and Sample Identification for Sampling Services." The sample location and corresponding sample numbers will be documented in the field logbook.

\subsubsection{Sample Analysis Report}

An approved Project Hanford Management Contract laboratory will be used to conduct laboratory analyses. The request for appropriate analyses will be included on the sample analysis request form as provided in SP 1-1, "Chain of Custody/Sample Analysis Request." Laboratory specific forms may be utilized in lieu of the site form and will be made available by the laboratory.

\subsubsection{Shipping}

Shipping requirements will conform with SP 2-6, "Sampling Packaging and Shipping."

\subsection{DECONTAMINATION}

Hand-held equipment used for the direct collection of samples will have been previously cleaned in accordance with SP 2-5, "Laboratory Cleaning of Sample Equipment."

\subsection{THERMOLUMINESCENT DOSIMETERS}

A network of TLDs is positioned in and around the 100 and 200 Areas to monitor dose rates from external radiation sources (primarily gamma rays). The environmental TLDs measure dose rates from all types of external radiation sources. These include cosmic radiation, naturally occurring radiation in air and soil, and fallout from nuclear weapons testing, as well as any contribution from the Hanford Site activities. These outside radiation sources cause an estimated $\pm 20 \%$ deviation in TLD analyses. The results are reported in units of millirems per year (mrem/yr).

The TLD measurements are taken to determine dose rates in the operations area environment. From these data, the contribution of the Hanford Site activities to the dose rates in these areas can be discerned.

The Hanford Site uses the Harshaw TLD system, which includes the Harshaw 8807

dosimeter and the Harshaw 8800 TLD reader. The TLD packaging, which uses an "O ring" seal, 
protects the TLDs from light, heat, moisture, and dirt. The TLDs are placed $1 \mathrm{~m}$ (approximately $3 \mathrm{ft}$ ) aboveground at each location. The TLDs are placed near active and inactive surface-water disposal sites and near facilities (tank farms, cribs, and the facility fence line). Changing conditions in the vicinity of the TLD sample locations, such as remediation activities, removal or storage of radioactive material, and tank farm operations may also cause fluctuations in TLD analyses over time. The TLDs are exchanged each calendar quarter.

Figure 8 indicates the locations of the existing TLD monitoring stations in the $100-\mathrm{K}$ Area. Currently there are no TLDs located proximal to the Cold Vacuum Drying Facility site. Four new TLD stations will be established around the Cold Vacuum Drying Facility site in the spring of 1999 .

The Current locations of the 200 East Area TLD monitoring stations are shown in Figure 9. Two additional TLD monitoring stations will be established in the spring of 1999 proximal to the CSB site.

\subsection{AIR MONITORING}

Ambient air monitoring is conducted to determine baseline concentrations of radionuclides in the operations areas, to assess the impact of operations on the local environment, and to monitor diffuse emissions from sources located within the operations area. These measurements also provide an indication of facility and/or project performance and are used to demonstrate compliance with environmental protection criteria.

The placement of air monitoring stations takes into consideration potential source terms as well as prevailing wind direction. Meteorological conditions are monitored continuously by Pacific Northwest National Laboratory meteorology stations, which are strategically positioned in and around the Hanford Site.

Hanford Site air samplers operate at a flow rate of $0.056 \mathrm{~m}^{3} / \mathrm{min}\left(2 \mathrm{ft}^{3} / \mathrm{min}\right)$, drawing a sample through a 47-mm (2-in.), open-faced filter about $2 \mathrm{~m}(6 \mathrm{ft})$ aboveground. Typically, sample filters are exchanged biweekly, held one week (to allow for decay of the short-lived natural radioactivity), and then sent to the analytical laboratory for initial analysis of total alpha and total beta activity. These initial analyses serve as an indicator of potential environmental problems.

The filters are stored until the end of the 6-month sampling period, then segregated and composited by sample location (or as deemed appropriate) for specific radionuclide analysis. Segregating and compositing air filters by site provides a larger sample size and, thus, a more sensitive and accurate measurement of the concentration of airborne radionuclides. 
HNF-SD-SNF-AP-003, Rev. 0

Figure 8. Map of 100-K Area Showing TLD Monitoring Locations.

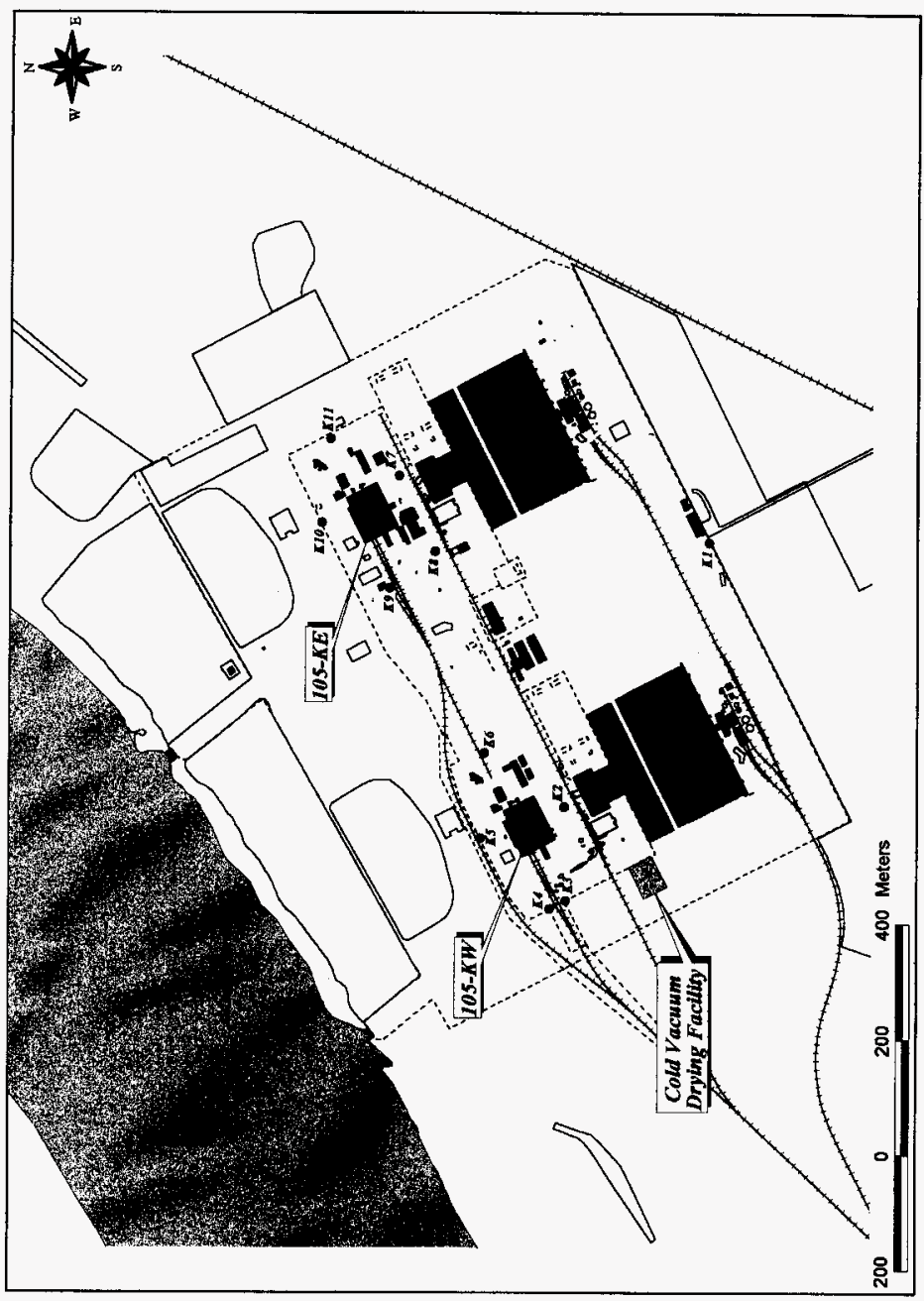


HNF-SD-SNF-AP-003, Rev. 0

Figure 9. TLD Monitoring Locations in 200 East Area.

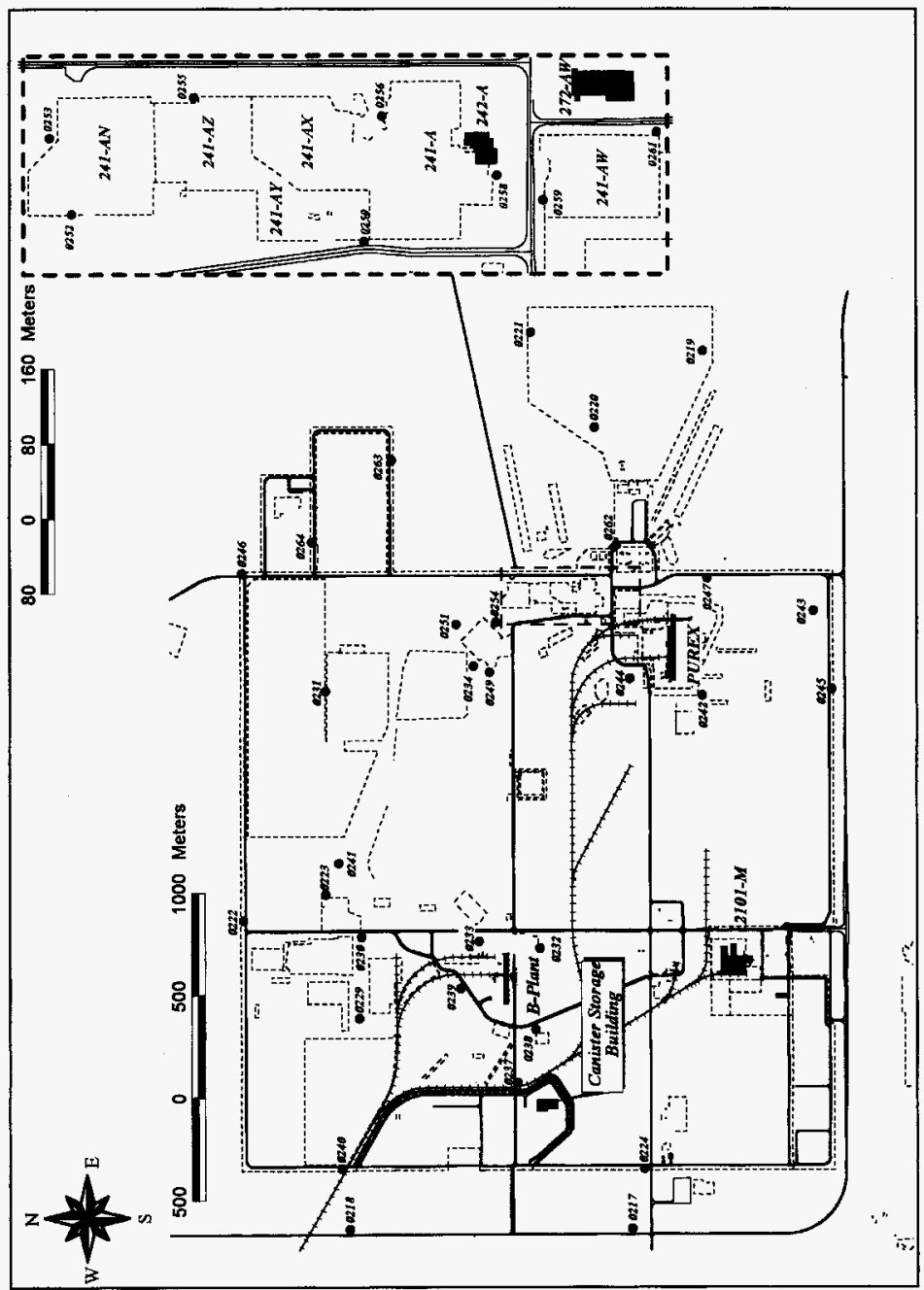


To help assess the impact of Site operations, monitoring results are compared to DOE derived concentration guides, to the results obtained from the distant communities of Yakima and Sunnyside (reported by the Pacific Northwest Site Environmental Surveillance Program) and to data acquired from distant station N-981 located at the Wye Barricade.

Figure 10 shows the locations of the ambient air samplers in the 100-K Area. Stations $\mathrm{N}-401, \mathrm{~N}-402, \mathrm{~N}-403$ and $\mathrm{N}-404$ in the $100-\mathrm{K}$ East Area have been in operation since March 1993. These samplers provide environmental monitoring data required by the Washington Department of Health for operation of the 105 K East Fuel Storage Basin. Stations N-476, $\mathrm{N}-477, \mathrm{~N}-478$ and $\mathrm{N}-479$ are similarly located in the 100-K West Area and became operational in February 1999. For approximately a year, these samplers will be collecting preoperational monitoring data as required by the U.S. Department of Energy (DOE 1988).

Table 3 provides five-year summaries (1993 through 1997) of the radioanalytical data collected from the four (4) samplers at $100-\mathrm{K}$ East and from the distant communities' sampling stations (1993 through 1996), as well as the corresponding derived concentration guides for each radionuclide. The analytical results for ${ }^{60} \mathrm{Co},{ }^{235} \mathrm{U}$ and ${ }^{238} \mathrm{Pu}$ for all locations frequently exhibit statistical uncertainties above $100 \%$ and/or average concentrations less than zero, indicating that these radionuclides are often below analytical detection levels. Only ${ }^{241} \mathrm{Am}$ was consistently detected at each sampling location. All other radionuclides shown in Table 3 are infrequently detected. Sampler $\mathrm{N}-401$ often exhibits the highest concentrations for the radionuclides, ${ }^{137} \mathrm{Cs}$, ${ }^{234} \mathrm{U},{ }^{239 / 240} \mathrm{Pu},{ }^{241} \mathrm{Pu}$ and ${ }^{241} \mathrm{Am}$.

Figure 11 shows the locations of the two new ambient air samplers (N-480 and N-481) near the CSB, as well as the existing stations in the 200 East Area. Four, preexisting sampling stations, situated in the general vicinity of the CSB, provide comparative data $(\mathrm{N}-967, \mathrm{~N}-973$, $\mathrm{N}-019$ and $\mathrm{N}-968)$.

Table 4 provides five-year summaries (1993 through 1997) of radioanalytical data collected from these four (4) samplers and from the distant communities' sampling stations (1993 through 1996), as well as the corresponding derived concentration guides for each radionuclide. The average analytical results for ${ }^{90} \mathrm{Sr},{ }^{235} \mathrm{U},{ }^{238} \mathrm{Pu}$ and ${ }^{239 / 240} \mathrm{Pu}$ for all locations frequently exhibited statistical uncertainties above $100 \%$ and/or average concentrations less than zero during the time period, indicating that these radionuclides are usually below analytical detection levels. ${ }^{234} \mathrm{U}$ and ${ }^{238} \mathrm{U}$ are frequently detected at most locations. ${ }^{60} \mathrm{Co}$ and ${ }^{137} \mathrm{Cs}$ are not consistently detected at any of the locations.

The analytical data now being acquired from the newly established environmental air samplers at the 100-K West and CSB, in conjunction with the data from the preexisting air samplers near these sites, will adequately assess the impact of construction and operation of the facilities, as well as meet the Washington Department of Health radioactive airborne permit approved conditions. 
HNF-SD-SNF-AP-003, Rev, 0

Figure 10. 100-K Area Showing the Location of Air Monitoring Stations

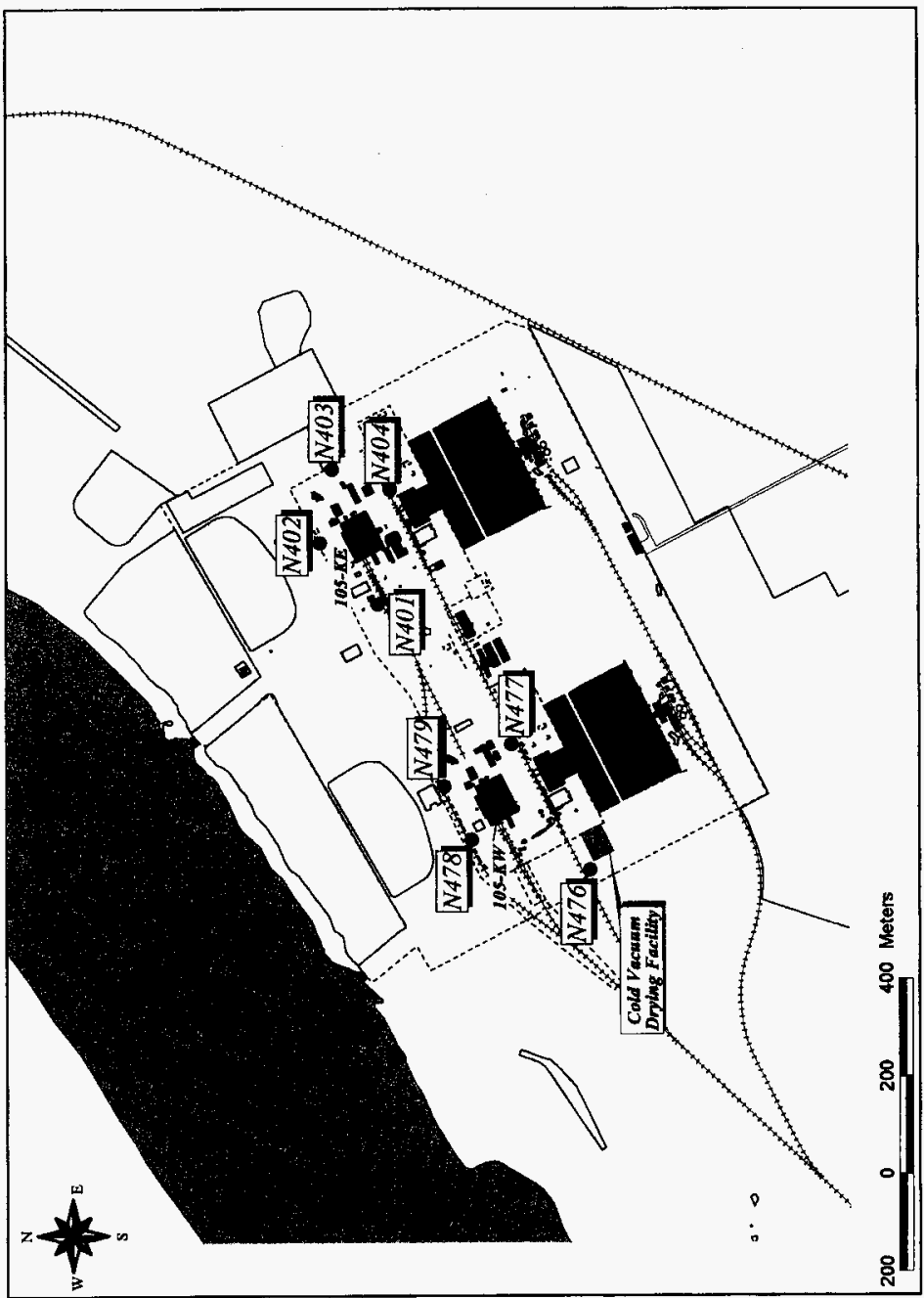


Table 3. 100-K Ambient Air Monitoring Results - Five Year Averages ( $\mathrm{pCi} / \mathrm{m}^{3}$ ).

\begin{tabular}{|c|c|c|c|c|c|c|}
\hline Radionuclide & $\mathrm{N}-401$ & $\mathrm{~N}-402$ & $\mathrm{~N}-403$ & $\mathrm{~N}-404$ & Distant Community ${ }^{*}$ & DCG \\
\hline $60 \mathrm{Co}$ & $-5.2 \mathrm{E}-05 \pm 328 \%$ & $-2.2 \mathbf{E}-04 \pm 237 \%$ & $-5.6 \mathrm{E}-05 \pm 224 \%$ & $-1.7 \mathrm{E}-04 \pm 264 \%$ & $1.0 \mathrm{E}-04 \pm 75 \%$ & $8.0 \mathrm{E}+01$ \\
\hline 90Sr & $3.7 \mathrm{E}-04 \pm 43 \%$ & $2.5 \mathrm{E}-04 \pm 103 \%$ & $2.2 \mathrm{E}-04 \pm 64 \%$ & $5.1 \mathrm{E}-04 \pm 169 \%$ & $3.0 \mathrm{E}-06 \pm 500 \%$ & $9.0 \mathrm{E}-00$ \\
\hline $137 \mathrm{Cs}$ & $2.6 \mathrm{E}-03 \pm 25 \%$ & $1.6 \mathrm{E}-04 \pm 109 \%$ & $3.0 \mathrm{E}-04 \pm 94 \%$ & $2.1 \mathrm{E}-04 \pm 218 \%$ & $4.7 \mathrm{E}-05 \pm 113 \%$ & $4.0 \mathrm{E}+02$ \\
\hline $234 \mathrm{U}$ & $2.3 \mathrm{E}-05 \pm 137 \%$ & $1.9 \mathrm{E}-05 \pm 119 \%$ & $1.7 \mathrm{E}-05 \pm 122 \%$ & $1.8 \mathrm{E}-05 \pm 83 \%$ & $2.0 \mathrm{E}-05 \pm 25 \%$ & $9.0 \mathrm{E}-02$ \\
\hline $235 \mathrm{U}$ & $9.2 \mathrm{E}-06 \pm 191 \%$ & $9.7 \mathrm{E}-06 \pm 184 \%$ & $8.0 \mathrm{E}-06 \pm 103 \%$ & $6.3 \mathrm{E}-06 \pm 128 \%$ & $8.5 \mathrm{E}-07 \pm 82 \%$ & $1.0 \mathrm{E}-01$ \\
\hline $238 \mathrm{U}$ & $1.2 \mathrm{E}-05 \pm 231 \%$ & $1.5 \mathrm{E}-05 \pm 48 \%$ & $1.1 \mathrm{E}-05 \pm 89 \%$ & $9.4 \mathrm{E}-06 \pm 111 \%$ & $1.7 \mathrm{E}-05 \pm 26 \%$ & $1.0 \mathrm{E}-01$ \\
\hline $238 \mathrm{Pu}$ & $-1.3 \mathrm{E}-06 \pm 229 \%$ & $-1.3 \mathrm{E}-06 \pm 241 \%$ & $6.1 \mathrm{E}-07 \pm 230 \%$ & $-1.7 \mathrm{E}-06 \pm 206 \%$ & $1.0 \mathrm{E}-07 \pm 240 \%$ & $3.0 \mathrm{E}-02$ \\
\hline 239/240Pu & $1.5 \mathrm{E}-05 \pm 105 \%$ & $8.3 \mathrm{E}-06 \pm 95 \%$ & $1.2 \mathrm{E}-05 \pm 83 \%$ & $6.4 \mathrm{E}-06 \pm 106 \%$ & $6.5 \mathrm{E}-07 \pm 110 \%$ & $2.0 \mathrm{E}-02$ \\
\hline $241 \mathrm{Pu}$ & $9.5 \mathrm{E}-04 \pm 95 \%$ & $2.2 \mathrm{E}-04 \pm 189 \%$ & $4.6 \mathrm{E}-04 \pm 171 \%$ & $7.0 \mathrm{E}-04 \pm 285 \%$ & Not Reported & $1 . \mathrm{E}-00$ \\
\hline $241 \mathrm{Am}$ & $3.0 \mathrm{E}-05 \pm 91 \%$ & $1.8 \mathrm{E}-05 \pm 55 \%$ & $2.0 \mathrm{E}-05 \pm 47 \%$ & $1.5 \mathrm{E}-05 \pm 63 \%$ & Not Reported & $2.0 \mathrm{E}-02$ \\
\hline
\end{tabular}

* 1993-1996 Annual Averages from PNNL-11795

$\mathrm{DCG}=$ Derived Concentration Guide 
HNF-SD-SNF-AP-003, Rev. 0

Figure 11. The 200 East Area Air Monitoring Locations.

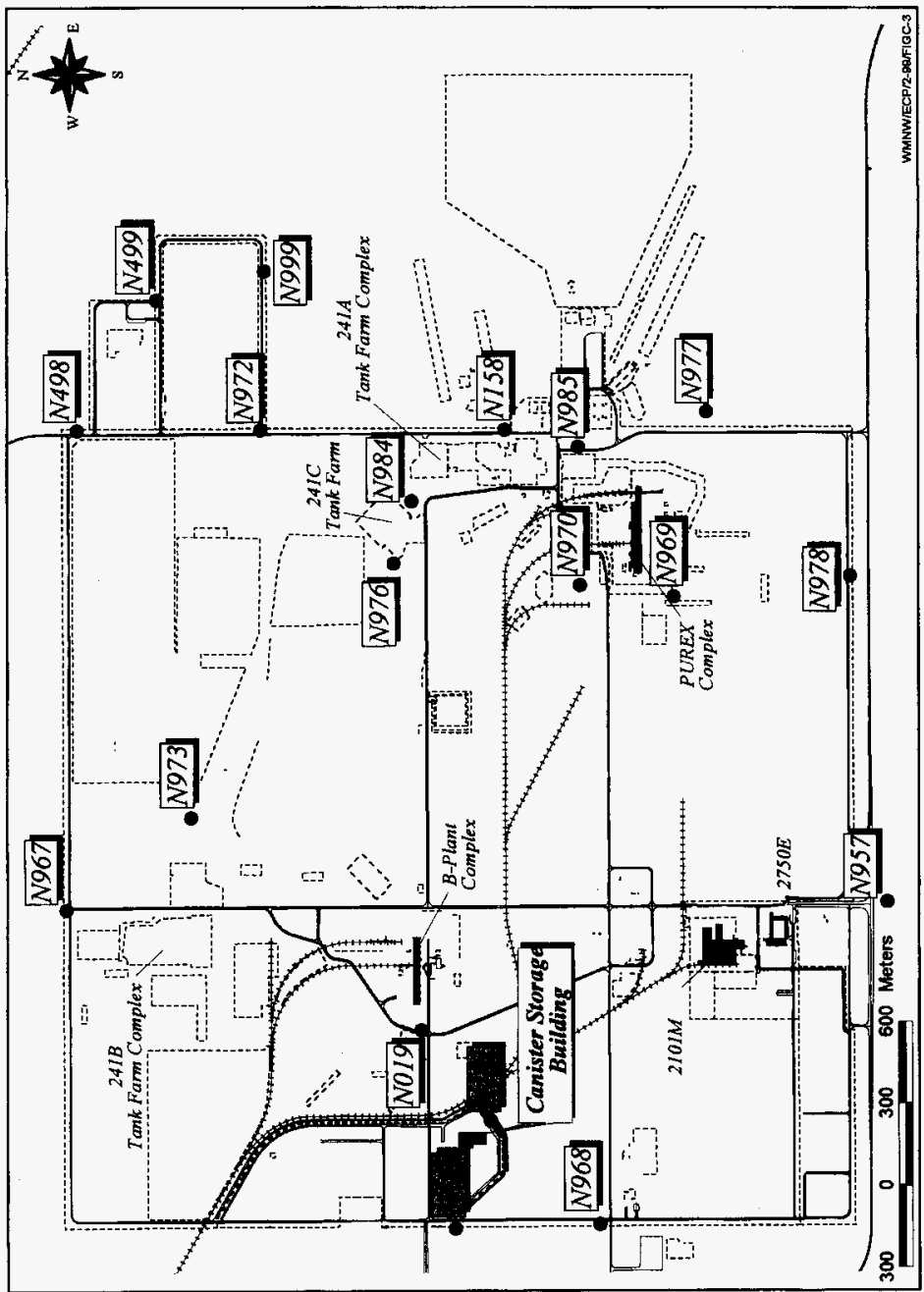


Table 4. 200 East Ambient Air Monitoring Results - Five Year Averages (pCi/m $\mathrm{m}^{3}$ ).

\begin{tabular}{|c|c|c|c|c|c|c|}
\hline \begin{tabular}{|l|} 
Radionuclide \\
\end{tabular} & $\mathrm{N}-967$ & N-973 & $\mathrm{N}-019$ & $\mathrm{~N}-968$ & Distant Community* & DCG \\
\hline $60 \mathrm{Co}^{\circ}$ & $-5.8 \mathrm{E}-05 \pm 238 \%$ & $1.9 \mathrm{E}-05 \pm 221 \%$ & $-3.7 \mathrm{E}-05 \pm 209 \%$ & $1.6 \mathrm{E}-04 \pm 43 \%$ & $1.0 \mathrm{E}-04 \pm 75 \%$ & $8.0 \mathrm{E}+01$ \\
\hline 90Sr & $3.0 \mathrm{E}-04 \pm 215 \%$ & $1.6 \mathrm{E}-04 \pm 102 \%$ & $1.4 \mathrm{E}-03 \quad \pm 118 \%$ & $2.3 \mathrm{E}-04 \pm 167 \%$ & $3.0 \mathrm{E}-06 \pm 500 \%$ & $9.0 \mathrm{E}-00$ \\
\hline $137 \mathrm{Cs}$ & $2.2 \mathrm{E}-04 \pm 123 \%$ & $3.4 \mathrm{E}-04 \pm 99 \%$ & $4.2 \mathrm{E}-03 \pm 122 \%$ & $7.9 \mathrm{E}-05 \pm 228 \%$ & $4.7 \mathrm{E}-05 \pm 113 \%$ & $4.0 \mathrm{E}+02$ \\
\hline $234 \mathrm{U}$ & $1.3 \mathrm{E}-05 \pm 104 \%$ & $1.3 \mathrm{E}-05 \pm 86 \%$ & $1.6 \mathrm{E}-05 \pm 99 \%$ & $1.9 \mathrm{E}-05 \pm 64 \%$ & $2.0 \mathrm{E}-05 \pm 25 \%$ & $9.0 \mathrm{E}-02$ \\
\hline $235 \mathrm{U}$ & $4.0 \mathrm{E}-06 \pm 221 \%$ & $4.8 \mathrm{E}-06 \pm 286 \%$ & $1.1 \mathrm{E}-05 \pm 146 \%$ & $8.3 \mathrm{E}-06 \pm 121 \%$ & $8.5 \mathrm{E}-07+82 \%$ & $1.0 \mathrm{E}-01$ \\
\hline 2380 & $1.0 \mathrm{E}-05 \pm 179 \%$ & $9.6 \mathrm{E}-06 \pm 90 \%$ & $9.9 \mathrm{E}-06 \pm 69 \%$ & $1.4 \mathrm{E}-05 \pm 68 \%$ & $1.7 \mathrm{E}-05 \pm 26 \%$ & $1.0 \mathrm{E}-01$ \\
\hline 238Pu & $-9.2 \mathrm{E}-07 \pm 409 \%$ & $1.8 \mathrm{E}-06 \pm 263 \%$ & $4.3 \mathrm{E}-06 \pm 297 \%$ & $-1.2 \mathrm{E}-06 \pm 261 \%$ & $1.0 \mathrm{E}-07+240 \%$ & $3.0 \mathrm{E}-02$ \\
\hline 239/240Pu & $1.3 \mathrm{E}-06 \pm 124 \%$ & $3.3 \mathrm{E}-06 \pm 167 \%$ & $7.9 \mathrm{E}-06 \pm 108 \%$ & $2.3 \mathrm{E}-06 \pm 116 \%$ & $6.5 \mathrm{E}-07 \pm 110 \%$ & $2.0 \mathrm{E}-02$ \\
\hline
\end{tabular}

* 1993-1996 Annual Averages from PNNL-11795.

DCG $=$ Derived Concentration Guide. 


\subsection{LABORATORY ANALYSIS}

Procedure SP 2-1, "Bottle Preservation," provides general guidance for containers and preservation requirements. The contractor laboratory may request modifications to these recommendations as long as the quality of the data is not compromised. Sample containers are purchased precleaned from a supplier providing certification of internal laboratory procedures, or from the contract laboratory when requested.

Samples collected for radionuclide analyses will be transported to the contract laboratory for processing. These samples will be analyzed for gamma spectroscopy to include ${ }^{241} \mathrm{Am}$. Additional analyses will include ${ }^{90} \mathrm{Sr}$, as well as isotopic plutonium and uranium.

The remaining samples will be transported to a contractor laboratory for analysis of metals, anions, and other analytes as requested. A complete list is provided in the sample analyses summary (Table 5).

Table 5. Sample Analyses Summary.

\begin{tabular}{|c|c|c|c|c|}
\hline Parameter/analysis & $\begin{array}{l}\text { Analytical } \\
\text { methods }\end{array}$ & Container $1 /$ volume & Preservation & Holding time \\
\hline ICP metals & 200.8 & \multirow{9}{*}{$\mathrm{G} 120 \mathrm{gm}$} & \multirow{6}{*}{ Cool to $4{ }^{\circ} \mathrm{C}$} & 6 months \\
\hline Arsenic & 200.8 & & & 6 months \\
\hline Lead & 200.8 & & & 6 months \\
\hline Isotopic uranium & 200.8 & & & \\
\hline Mercury & 200.8 & & & 28 days \\
\hline Cyanide & 335.3 & & & 14 days \\
\hline Anions & \multirow{3}{*}{ EPA 300.0} & & \multirow{3}{*}{ Cool to $4{ }^{\circ} \mathrm{C}$} & \\
\hline $\mathrm{SO}_{4}, \mathrm{~F}, \mathrm{Cl}$ & & & & 28 days \\
\hline $\mathrm{NO}_{2}, \mathrm{NO}_{3}, \mathrm{PO}_{4}$ & & & & 48 hours \\
\hline Gamma scan & LA-508-462 & \multirow{4}{*}{$\mathrm{P}$ (sq.) $500 \mathrm{gm}$} & \multirow[b]{4}{*}{ None } & \multirow[b]{4}{*}{6 months } \\
\hline${ }^{90} \mathrm{Sr}$ & LA-508-415 & & & \\
\hline${ }^{241} \mathrm{Am}$ & LA-508-462 & & & \\
\hline $238,{ }_{239 / 240 / 241} \mathrm{Pu}$ & LA-508-462/421 & & & \\
\hline PCBs/Pesticides & $8082 / 8081 \mathrm{~A}$ & $\mathrm{G} 100 \mathrm{gm}$ & Cool to $4{ }^{\circ} \mathrm{C}$ & 14 days \\
\hline
\end{tabular}


HNF-SD-SNF-AP-003, Rev. 0

\subsection{QUALITY ASSURANCE/QUALITY CONTROL}

Quality assurance/quality control (QA/QC) samples are collected to provide for determination of field and laboratory QA/QC levels (HNF-EP-0538-3, WMNW 1997). Three types of (QA/QC) samples will be collected in the field:

- A duplicate sample will be collected from the same location, then submitted as two separate samples for separate analysis at the same laboratory.

- A split sample will be collected from the same locations, but will be sent to two different laboratories; one sample will be sent to the primary laboratory, the second will be sent to an independent laboratory.

- An equipment blank of clean silica sand will be submitted to verify the cleanliness of the decontaminated sampling equipment.

The number of QA/QC samples required will conform to one each of the above designated samples collected/processed per 20 soil samples as a minimum. QA/QC samples required for vegetation will be limited to duplicate and split samples. Because of the uniqueness of the media, small mammals will not be submitted for QA/QC purposes.

Personnel from the Washington State Department of Health (Office of Radiation Protection) may collect split samples of soil and vegetation and be analyzed by comparable methods for the selected constituents. Soil samples will be collected and split in accordance with standard methods used by WDOH for surface soil sampling. In order to reduce costs, the samples sent to the Washington Department of Health laboratory can be considered to represent the split sample described above.

\subsection{SCHEDULE}

Sampling of the multiplicity of media identified will require a precise coordination of effort, depending on growth patterns of vegetation, animal activity, and availability of the media. If field conditions permit, it would be preferable to sample all the required media at the site over a three to five day period. That synchronization of effort will be the goal of the sample scheduling of this project. However, if environmental conditions are not favorable, sampling may take place over several days, or weeks as necessary.

In order to meet the requirements of DOE 5400.1 to include seasonal variability, additional samples may be collected from selected sample sites. These will allow comparisons with the radionuclide and metals data obtained previously. 


\subsection{SAMPLING AND ANALYSIS PLAN MODIFICATIONS}

Under field conditions, the optimal aspects of preliminary sample design are not always achievable. Factors influencing these efforts can be equipment malfunction or breakdown, weather conditions, improper equipment, soil conditions, physical barriers to sampling equipment, and overly optimistic evaluation of capabilities. Because of unforeseen field conditions, modifications to the planned activity may be necessary as decided by the Field Team Leader.

To ensure efficient and timely completion of tasks, minor field changes can be made in the field by the person in charge of the particular activity. Minor field changes are those that have no adverse effects on the technical adequacy of the job or the work schedule. Such changes will be documented in the daily logbooks that are maintained in the field.

Major changes to this plan will be submitted on a Project Change Form. The change will require at least the verbal approval of the Field Team Leader and the project coordinator. The change will be filed, and a copy will be kept with the project file. 
HNF-SD-SNF-AP-003, Rev. 0

\subsection{REFERENCES}

10 CFR 834, 1998, "Radiological Protection of the Public and the Environment," Code of Federal Regulations, as amended.

Chatters, J. C. and N. A. Cadoret, 1990, Archaeological Survey of the 200-East Area 200-West Area, Hanford Site, Washington, PNL-7264, Pacific Northwest Laboratory, Richland, Washington.

DOE, 1998, Supplement Analysis of Environmental Effects of Changes in DOE's Preferred Alternative for Management of Spent Nuclear Fuel from the $K$ Basins at the Hanford Site, Richland, Washington, DOE/EIS-0245/SA1, U.S. Department of Energy, Richland Operations Office, Richland, Washington.

DOE, 1996, Management of Spent Nuclear Fuel from the $K$ Basins at the Hanford Site, Richland, Washington, Addendum, Final Environmental Impact Statement, DOE/EIS-0245F, U.S. Department of Energy, Richland, Washington.

DOE, 1995, Draft Environmental Impact Statement Management of Spent Nuclear Fuel from the $K$ Basins at the Hanford Site, Richland, Washington, DOE/EIS-0245D, U.S. Department of Energy, Richland, Washington.

DOE, 1991, Environmental Regulatory Guide for Radiological Effluent Monitoring and Environmental Surveillance, DOE/EH-0173T, U.S. Department of Energy, Washington, D.C.

DOE, 1990a, Radiation Protection of the Public and the Environment, DOE Order 5400.5, U.S. Department of Energy, Washington, D.C.

DOE, 1990b, Low Level Waste Management Handbook Series: Environmental Monitoring for Low Level Waste Disposal Sites, DOE-LLW-13Tg, Rev. 2, Washington, D.C.

DOE, 1988a, General Environmental Protection Program, DOE Order 5400.1, U.S. Department of Energy, Washington, D.C.

DOE, 1988b, Radioactive Waste Management, DOE Order 5820.2A, U.S. Department of Energy, Washington, D.C.

DOE, 1981, Environmental Protection, Safety, and Health Protection Information Reporting Requirements, DOE Order 5484.1, U.S. Department of Energy, Washington, D.C.

EPA, 1986, Test Methods for Evaluating Solid Waste, SW-846, $3^{\text {rd }}$ Edition, EPA/Office of Solid Waste and Emergency Response, U.S. Environmental Protection Agency, Washington, D.C. 
FDH, 1998, Environmental Training, HNF-PRO-459, Fluor Daniel Hanford, Inc., Richland, Washington.

FDH, 1998, Quality Assurance Program Plans, HNF-PRO-261, Fluor Daniel Hanford, Inc., Richland, Washington.

Fitzner, R. E., S. G. Weiss, and J. A. Stegen, 1992, Biological Assessment for Threatened and Endangered Wildlife Species, Related to CERCLA Characterization Activities, WHC-EP-0513, Westinghouse Hanford Company, Richland, Washington.

Houston, J. R. and P. J. Blumer, 1978, Environmental Status of the Hanford Site for Calendar Year 1977, PNL-2677, Battelle, Pacific Northwest Laboratory, Richland, Washington.

Houston, J. R. and P. J. Blumer, 1979a, Environmental Surveillance at Hanford for Calendar Year 1978, PNL-2932, Battelle, Pacific Northwest Laboratory, Richland, Washington.

Houston, J. R. and P. J. Blumer, 1979b, Environmental Status of the Hanford Site for Calendar Year 1978, PNL-2933, Battelle, Pacific Northwest Laboratory, Richland, Washington.

Johnson, A. R. and R. M. Mitchell, 1996, Preoperational Environmental Survey Report: 200 Areas Cross-Site Transfer Line Replacement (W-058), WHC-SD-W058-RPT-001, Westinghouse Hanford Company, Richland, Washington.

Landeen, D. S., A. R. Johnson, and R. M. Mitchell, 1992, Status of Birds at the Hanford Site in Southeastern Washington, WHC-EP-0402, Rev. 1, Westinghouse Hanford Company, Richland, Washington.

Miller, M. L., J. J. Fix and P. E. Bramson, 1977, Radiochemical Analysis of Soil and Vegetation Samples Taken from the Hanford Environs, 1971-1976, BNWL-2249, Battelle Northwest Laboratories, Richland, Washington.

Neitzel, D. A., 1997, Hanford Site National Environmental Policy Act (NEPA) Characterization, PNL-6415, Rev 9, Pacific Northwest National Laboratory, Richland, Washington.

Panesko, J. V., G. H. Carbough, D. J. Carrell, R. L. Dirkes, R. L. Laughman, H. L. Maxfield, and R. E. Wheeler, 1977, Environmental Protection Annual Report Calendar Year 1976, ARH-LD-154, Atlantic Richfield Hanford Company, Richland, Washington.

Panesko, J. V., R. L. Dirkes, K. Kover, and R. E. Wheeler, 1978, Environmental Protection Annual Report Calendar Year 1977, RHO-LD-78-75, Rockwell Hanford Operations, Richland, Washington.

Perkins, C. J., 1988, Westinghouse Hanford Company Environmental Surveillance Annual Report-100 Areas, Calendar Year 1987, WHC-EP-0161, Westinghouse Hanford Company, Richland, Washington. 
Perkins, C. J., 1990, Westinghouse Hanford Company Environmental Surveillance Annual Report-100 Areas CY 1988, WHC-EP-0258, Westinghouse Hanford Company, Richland, Washington.

Perkins, C. J., 1991, Westinghouse Hanford Company Environmental Surveillance Annual Report-100 Areas CY 1989, WHC-EP-0258-1, Westinghouse Hanford Company, Richland, Washington.

Perkins, C. J., 1992, Westinghouse Hanford Company Environmental Surveillance Annual Report - 100 Areas CY 1990, WHC-EP-0258-2, Westinghouse Hanford Company, Richland, Washington.

Perkins, C. J., A. R. Johnson, B. M. Markes, S. M. McKinney, and R. M. Mitchell, 1998, Hanford Site Near-Facility Environmental Monitoring Annual Report, Calendar Year 1997, HNF-EP-0573-6, Waste Management Federal Services, Inc., Northwest Operations for Fluor Daniel Hanford, Inc., Richland, Washington.

Perkins, C. J., A. R. Johnson, B. M. Markes, S. M. McKinney, and R. M. Mitchell, 1997, Hanford Site Near-Facility Environmental Monitoring Annual Report, Calendar Year 1996, HNF-EP-0573-5, Waste Management Federal Services, Inc., Northwest Operations for Fluor Daniel Hanford, Inc., Richland, Washington.

Sackschewsky, M. R., D. S. Landeen, G. I. Baird, W. H. Richard, and J. L. Downs, 1992, Vascular Plants of the Hanford Site, WHC-EP-0554, Westinghouse Hanford Company, Richland, Washington.

Schmidt, J. W., C. R. Huckfeldt, A. R. Johnson, and S. M. McKinney, 1990, Westinghouse Hanford Company Environmental Surveillance Annual Report-200/600 Areas, Calendar Year 1989, WHC-EP-0145-2, Westinghouse Hanford Company, Richland, Washington.

Schmidt, J. W., A. R. Johnson, S. M. McKinney, and C. R. Webb, 1992a, Westinghouse Hanford Company Environmental Surveillance Annual Report - 200/600 Areas, Calendar Year 1990, WHC-EP-0145-4, Westinghouse Hanford Company, Richland, Washington.

Schmidt, J. W., A. R. Johnson, S. M. McKinney, C. J. Perkins, and C. R. Webb, 1992b, Westinghouse Hanford Company Environmental Surveillance Annual Report - Calendar Year 1991, WHC-EP-0573, Westinghouse Hanford Company, Richland, Washington.

Schmidt, J. W., A. R. Johnson, S. M. McKinney, and C. J. Perkins, 1993, Westinghouse Hanford Company Operational Environmental Monitoring Annual Report, CY 1992, WHC-EP-0573-1, Westinghouse Hanford Company, Richland, Washington. 
Schmidt, J. W., A. R. Johnson, B. M. Markes, S. M. McKinney, and C. J. Perkins, 1994, Westinghouse Hanford Company Operational Environmental Monitoring Annual Report, Calendar Year 1993, WHC-EP-0573-2, Westinghouse Hanford Company, Richland, Washington.

Schmidt, J. W., J. W. Fassett, A. R. Johnson, V. G. Johnson, B. M. Markes, S. M. McKinney, K. J. Moss, C. J. Perkins, and L. R. Richterich, 1995, Westinghouse Hanford Company Operational Environmental Monitoring Annual Report, CY 1994, WHC-EP-0573-3, Westinghouse Hanford Company, Richland, Washington.

Schmidt, J. W., J. W. Fassett, V. G. Johnson, R. M. Mitchell, B. M. Markes, S. M. McKinney, K. J. Moss, C. J. Perkins, 1996, Westinghouse Hanford Company Operational Environmental Monitoring Annual Report, CY 1995, WHC-EP-0573-4, Westinghouse Hanford Company, Richland, Washington.

Stegen, J. A., 1992, Biological Assessment for State Candidate and Monitor Wildlife Species Related to CERCLA, WHC-SD-EN-EE-009, Westinghouse Hanford Company, Richland, Washington.

Washington Natural Heritage Program, 1994, Endangered, Threatened and Sensitive Vascular Plants of Washington, Washington State Department of Natural Resources, Olympia, Washington.

Wasmiller, M. A., 1993, Hanford Waste Vitrification Plant Soil Baseline Summary Report, WHC-SD-HWV-TI-033, Westinghouse Hanford Company, Richland, Washington.

WMNW, 1997, Near-Facility Environmental Monitoring Quality Assurance Project Plan, HNF-EP-0538-3, Waste Management Federal Services, Inc., Northwest Operations, Richland, Washington.

WMNW, 1998, Sampling Services Procedures Manual, ES-SSPM-001, Waste Management Federal Services, Inc., Northwest Operations, Richland, Washington.

WMNW, Operational Environmental Monitoring, WMNW-CM-004, Waste Management Federal Services, Inc., Northwest Operations, Richland, Washington.

WMNW, Safety and Environmental Reference Manual, WMNW-SERM-001, Waste Management Federal Services, Inc., Northwest Operations, Richland, Washington.

Wheeler, R. E. and A. G. Law, 1980, Rockwell Hanford Operations Environmental Surveillance for Calendar Year 1979, RHO-LD-132, Rockwell Hanford Operations, Richland, Washington. 


\section{DISTRIBUTION SHEET}

\begin{tabular}{|c|c|c|c|c|c|}
\hline \multirow{2}{*}{$\begin{array}{l}\text { To } \\
\text { Distribution }\end{array}$} & \multirow{2}{*}{\multicolumn{3}{|c|}{$\begin{array}{l}\text { From } \\
\text { WMNW EM\&I }\end{array}$}} & \multicolumn{2}{|l|}{ Page 1 of 1} \\
\hline & & & & \multicolumn{2}{|c|}{ Date Feb. 24, 1999} \\
\hline \multicolumn{4}{|l|}{ Project Title/Work Order } & \multicolumn{2}{|c|}{ EDT No. 620481} \\
\hline \multicolumn{4}{|c|}{$\begin{array}{l}\text { Sampling and Analysis Plan for the Preoperational Environmental } \\
\text { Survey of the Spent Nuclear Fuel Project Facilities } \\
\text { (HNF-SD-SNF-AP-003, Rev. O) }\end{array}$} & \multicolumn{2}{|l|}{ ECN No. N/A } \\
\hline Name & MSIN & $\begin{array}{l}\text { Text } \\
\text { With All } \\
\text { Attach. }\end{array}$ & Text Only & $\begin{array}{l}\text { Attach./ } \\
\text { Appendix } \\
\text { Only }\end{array}$ & $\begin{array}{l}\text { EDT/ECN } \\
\text { Only }\end{array}$ \\
\hline $\begin{array}{l}\text { G. D. Bazinet } \\
\text { P. K. Brockman } \\
\text { L. P. Diediker } \\
\text { J. J. Dorian } \\
\text { J. B. Hall } \\
\text { A. R. Johnson } \\
\text { B. M. Markes } \\
\text { S. M. McKinney } \\
\text { R. M. Mitchel1 (10) } \\
\text { D. J. Moak } \\
\text { C. J. Perkins } \\
\text { C. C. Pitkoff } \\
\text { J. E. Turnbaugh } \\
\text { D. J. Watson } \\
\text { Document Processing Center } \\
\text { Records Management (S. Myers) } \\
\text { RL Reading Room }\end{array}$ & $\begin{array}{l}S 8-06 \\
H 1-11 \\
H 6-36 \\
H 1-13 \\
H 1-14 \\
H 1-13 \\
H 1-13 \\
H 1-13 \\
H 1-13 \\
H 1-11 \\
H 1-13 \\
R 3-86 \\
X 3-79 \\
X 3-79 \\
B 1-07 \\
H 1-15 \\
H 2-53\end{array}$ & $\begin{array}{l}x \\
x \\
x \\
x \\
x \\
x \\
x \\
x \\
x \\
x \\
x \\
x \\
x \\
x \\
x \\
x \\
x \\
x \\
x\end{array}$ & & & \\
\hline \multicolumn{6}{|c|}{ Washington State Department of Health } \\
\hline \multicolumn{6}{|l|}{$\begin{array}{l}\text { Division of Radiation Protection } \\
\text { Airdustrial Center, B1dg. } 5 \\
\text { P.0. Box } 47827 \\
\text { Olympia, WA } 98504-0095\end{array}$} \\
\hline R. A. Danielson & MS-7827 & $x$ & & & \\
\hline
\end{tabular}

